\title{
FIELD GUIDE FOR COLLECTING AND PROCESSING STREAM-WATER SAMPLES FOR THE NATIONAL WATER-QUALITY ASSESSMENT PROGRAM
}

By Larry R. Shelton

U.S. GEOLOGICALL SURVEY

Open-File Report 94-455 


\section{U.S. DEPARTMENT OF THE INTERIOR \\ BRUCE BABBITT, Secretary}

\section{U.S. GEOLOGICAL SURVEY \\ GORDON P. EATON, Director}

Any use of trade, product, or firm names in this publication is for descriptive purposes only and does not imply endorsement by the U.S. Government.

For sale by the

U.S. Geological Survey

Earth Science Information Center

Open-File Reports Section

Box 25286, MS 517

Denver Federal Center

Denver, CO 80225

For additional information write to:

Chief, Pesticides National Synthesis Project, NAWQA

U.S. Geological Survey

Federal Building, Room W-2233

2800 Cottage Way

Sacramento, CA 95825 


\section{FIELD GUIDE FOR COLLECTING AND PROCESSING \\ STREAM-WATER SAMPLES FOR THE NATIONAL. WATER-QUALITY ASSESSMENT PROGRAM}

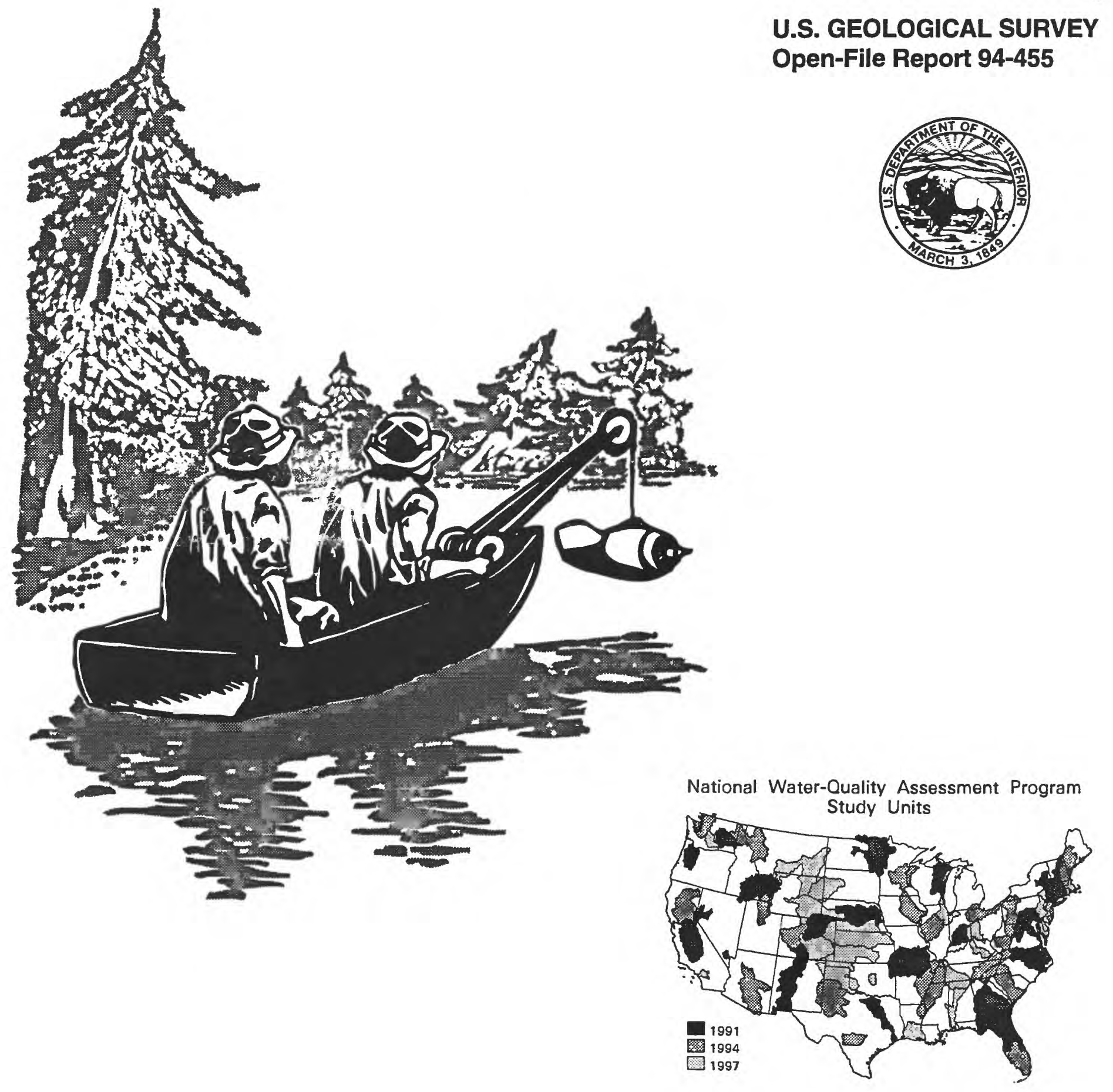




\section{CONTENTS}

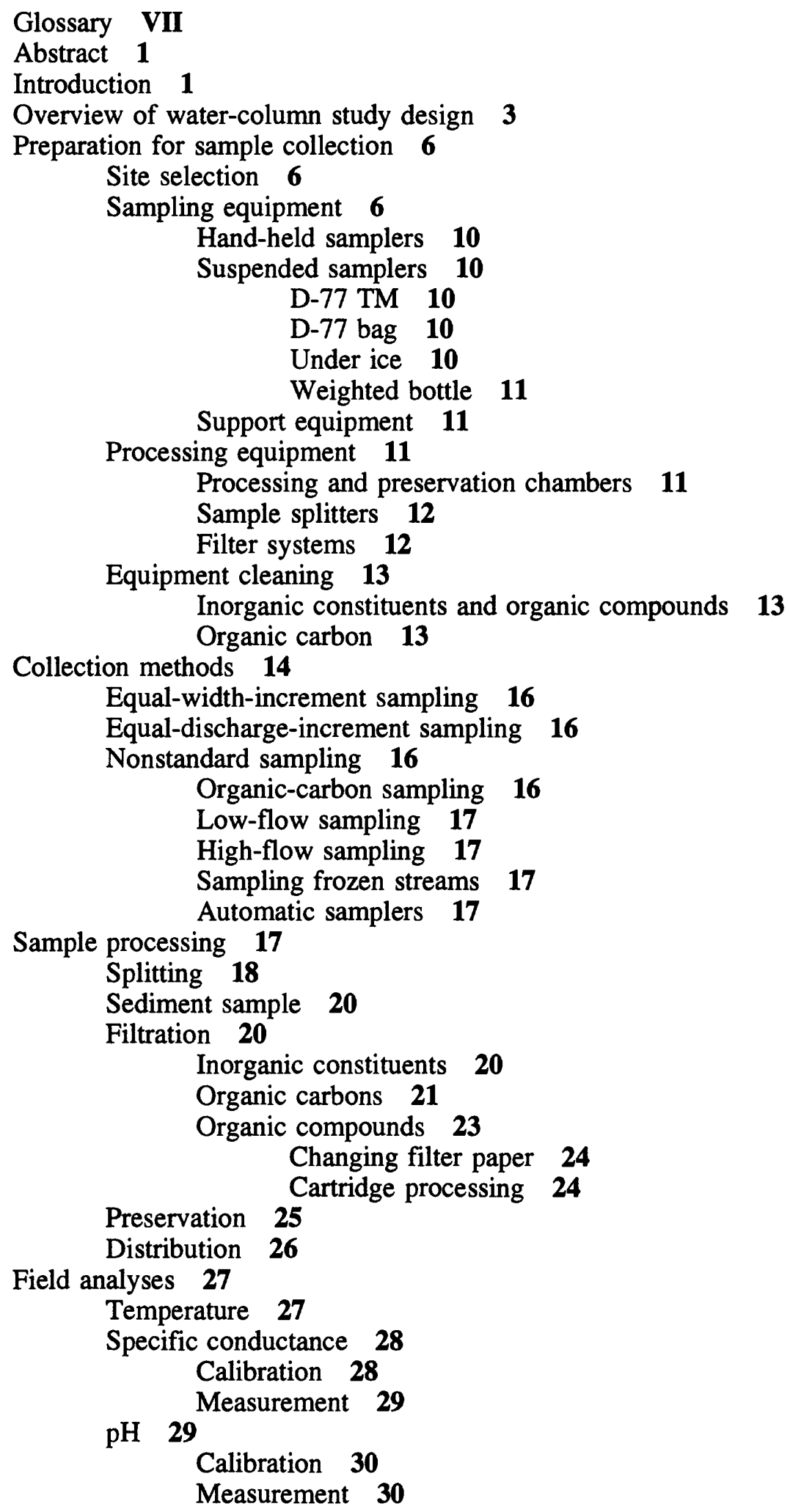


Field analyses--Continued

Alkalinity, bicarbonate, and carbonate $\mathbf{3 1}$

Fixed end-point method 31

Incremental method 31

Dissolved oxygen $\mathbf{3 3}$

Probe maintenance 33

Calibration 34

Barometer calibration 34

Air-calibration chamber in water $\mathbf{3 4}$

Air-saturated water 36

Documentation 37

Quality assurance and quality control 39

Field blanks 39

Replicates 39

Field-matrix spikes 39

References cited $\mathbf{4 0}$

Appendix A. Selected technical memorandums $\mathbf{4 1}$

Appendix B. Selected internal communications $\mathbf{4 2}$

\section{FIGURES}

1. Suggested water-quality samplers for various stream regimes 15

2. Example of form for recording surface-water quality field notes $\mathbf{3 8}$

\section{TABLES}

1. Analytical strategy for Basic Fixed Sites 4

2. Analytical strategy for Intensive Fixed Sites in addition to Basic Fixed Site analyses 5

3. List of equipment and supplies for sampling and processing stream-water samples 7

4. Solubility of dissolved oxygen in water at various temperatures and pressures $\mathbf{3 5}$ 
CONVERSION FACTORS, VERTICAL DATUM, ABBREVIATIONS, AND ACRONYMS

Conversion Factors

\begin{tabular}{rcl}
\hline Multiply & By & To obtain \\
\hline foot $(\mathrm{ft})$ & 0.3048 & meter \\
foot per second (ft/s) & 0.3048 & meter per second \\
gallon (gal) & 3.785 & liter \\
inch (in.) & 25.4 & millimeter \\
inch per second (in/s) & 25.4 & millimeter per second \\
pound, avoirdupois (lb) & 4.536 & kilogram \\
pound per square inch (lb/in $\left.{ }^{2}\right)$ & 6.895 & kilopascal \\
square mile $\left(\mathrm{mi}^{2}\right)$ & 2.590 & square kilometer
\end{tabular}

Temperature is given in degrees Celsius $\left({ }^{\circ} \mathrm{C}\right)$, which can be converted to degrees Fahrenheit $\left({ }^{\circ} \mathrm{F}\right)$ by the following equation:

$$
{ }^{\circ} \mathrm{F}=1.8\left({ }^{\circ} \mathrm{C}\right)+32
$$

\section{Vertical Datum}

Sea level: In this report, "sea level" refers to the National Geodetic Vertical Datum of 1929-a geodetic datum derived from a general adjustment of the first-order level nets of the United States and Canada, formerly called Sea Level Datum of 1929. 


\author{
Abbreviations \\ $\mathrm{cm}$, centimeter \\ $\mathrm{g} / \mathrm{L}$, gram per liter \\ L, liter \\ $\mu \mathrm{L}$, microliter \\ $\mu \mathrm{m}$, micrometer \\ $\mu \mathrm{S} / \mathrm{cm}$, microsiemens per centimeter at 25 degrees Celsius \\ $\mathrm{mg} / \mathrm{L}$, milligram per liter \\ $\mathrm{mg} / \mu \mathrm{L}$, milligram per microliter \\ $\mathrm{mL}$, milliliter \\ $\mathrm{mL} / \mathrm{min}$, milliliter per minute \\ $\mathrm{mm}$, millimeter \\ DIW deionized water \\ DOC dissolved organic carbon \\ EDI equal-discharge increment \\ EWI equal-width increment \\ FA filtered acidified \\ FC filtered chilled \\ FU filtered untreated \\ GCMS gas chromatography/mass spectrometer \\ HPLC high-pressure liquid chromatography \\ $\mathrm{N}$ normal \\ OCALA Quality Water Service Unit, USGS, Ocala, Florida \\ PPB parts per billion \\ PVC polyvinyl chloride \\ RC raw (unfiltered) chilled \\ RU raw (unfiltered) untreated \\ SOC suspended-organic carbon \\ SPE solid-phase extraction \\ TOC toxic organic compounds \\ VOC volatile organic compound
}

\title{
Acronyms
}

ASTM American Society for Testing and Materials

HIF Hydrologic Instrumentation Facility, USGS, Mississippi

NAWQA National Water-Quality Assessment

NWQL National Water Quality Laboratory

OSW Office of Surface Water

OWQ Office of Water Quality

TWRI Techniques of Water-Resources Investigations

USGS U.S. Geological Survey

WRD Water Resources Division

YSI Yellow Springs Instrument 


\section{GLOSSARY}

Basic Fixed Sites-Sites on streams at which streamflow is measured and samples are collected for temperature, salinity, suspended sediment, major ions and metals, nutrients, and organic carbon to assess the broad-scale spatial and temporal character and transport of inorganic constituents of stream water in relation to hydrologic conditions and environmental settings.

Bed-Sediment and Tissue Studies-Assessment of concentrations and distributions of trace elements and hydrophobic organic contaminants in stream bed sediment and tissues of aquatic organisms to identify potential sources and assess spatial distribution.

Depth-integrating sampler-A sampler that will integrate and represent the area of a stream section.

Discharge-weighted samplers-A sampler that will isokinetically represent the stream flow.

Ecological Studies-Studies of biological communities habitat characteristics to evaluate the effects of physical and chemical characteristics of water and hydrologic conditions on aquatic biota and to determine how biological and habitat characteristics differ among environmental settings in Study Units.

Equal-width increment (EWI) sampling-A composite sample across a section of stream with equal spacing between verticals and equal transit rates within each vertical that yields a representative sample of stream conditions.

Gaging station-A fixed site on a stream or river where hydrologic and environmental data are collected.

Indicator Sites-Stream sampling sites located at outlets of drainage basins with relatively homogeneous land use and physiographic conditions. Basins are as large and representative as possible, but still encompassing primarily one Environmental Setting (typically, 50 to $500 \mathrm{~km}^{2}$ ).

Integrator Site-Stream sampling sites located downstream of drainage basins that are large and complex and often contain multiple Environmental Settings. Most Integrator Sites are on major streams with drainage basins that include a substantial portion of the Study Unit area (typically, 10 to 100 percent).

Intensive Fixed Sites-Basic Fixed Sites with increased sampling frequency during selected seasonal periods and analysis of dissolved pesticides for 1 year. Most Study Units have one or two integrator Intensive Fixed Sites and one to four indicator Intensive Fixed Sites.

Isokinetic sampling - The water entering the sampler is hydrodynamically equivalent (velocity, area, and direction) to the portion of the stream being sampled.

Occurrence and Distribution Assessment-Assessment of the broad-scale geographic and seasonal distributions of water-quality conditions for surface and ground water of a Study Unit in relation to major contaminant sources and background conditions.

Solid-phase extraction (SPE) - A procedure to isolate specific organic compounds onto a bonded silica extraction column.

Study Unit-A major hydrologic system of the United States in which NAWQA studies are focused. NAWQA Study Units are geographically defined by a combination of ground- and surface-water features and usually encompass more than $10,000 \mathrm{~km}^{2}$ of land area. The NAWQA design is based on assessment of 60 Study Units, which collectively cover a large part of the Nation, encompass the majority of population and water use, and include diverse hydrologic systems that differ widely in natural and human factors that affect water quality.

Water-Column Studies-Assessment of physical and chemical characteristics of stream water, including suspended sediment, dissolved solids, major ions and metals, nutrients, organic carbon, and dissolved pesticides, in relation to hydrologic conditions, sources, and transport. 


\title{
FIELD GUIDE FOR COLLECTING AND PROCESSING STREAM-WATER SAMPLES FOR THE NATIONAL WATER-QUALITY ASSESSMENT PROGRAM
}

\author{
By Larry R. Shelton
}

\begin{abstract}
The U.S. Geological Survey's National Water-Quality Assessment program includes extensive data-collection efforts to assess the quality of the Nation's streams. These studies require analyses of stream samples for major ions, nutrients, sediments, and organic contaminants. For the information to be comparable among studies in different parts of the Nation, consistent procedures specifically designed to produce uncontaminated samples for trace analysis in the laboratory are critical. This field guide describes the standard procedures for collecting and processing samples for major ions, nutrients, organic contaminants, sediment, and field analyses of conductivity, $\mathrm{pH}$, alkalinity, and dissolved oxygen. Samples are collected and processed using modified and newly designed equipment made of Teflon to avoid contamination, including nonmetallic samplers (D-77 and DH-81) and a Teflon sample splitter. Field solid-phase extraction procedures developed to process samples for organic constituent analyses produce an extracted sample with stabilized compounds for more accurate results. Improvements to standard operational procedures include the use of processing chambers and capsule filtering systems. A modified collecting and processing procedure for organic carbon is designed to avoid contamination from equipment cleaned with methanol. Quality assurance is maintained by strict collecting and processing procedures, replicate sampling, equipment blank samples, and a rigid cleaning procedure using detergent, hydrochloric acid, and methanol.
\end{abstract}

\section{INTRODUCTION}

The National Water-Quality Assessment (NAWQA) program of the U.S. Geological Survey (USGS) is designed to assess the status and trends in the quality of the Nation's ground- and surface-water resources and to develop an understanding of the major factors that affect water-quality conditions (Hirsch and others, 1988; Leahy and others, 1990; Gilliom and others, 1994). The design is based on balancing the unique assessment requirements of individual hydrologic systems with a nationally consistent design structure that incorporates a multiscale, interdisciplinary approach. Investigations of water quality in 60 major hydrologic basins and aquifer systems, referred to as NAWQA Study Units, form the building blocks of the program.

The Occurrence and Distribution Assessment, described in Gilliom and others (1994), is the largest and most important component of the first intensive study phase in each Study Unit. The goal of the Occurrence and Distribution Assessment is to characterize, in a nationally consistent manner, the broadscale geographic and seasonal distribution of water-quality conditions in relation to major contaminant sources and background conditions. The national study design for streams has three interrelated components. Water-Column Studies assess the occurrence and distribution of major ions, nutrients, and dissolved pesticides and their relation to hydrologic conditions, sources, and transport. Bed-Sediment and Tissue Studies assess the occurrence and spatial distribution of trace elements and hydrophobic organic 
contaminants. Ecological Studies evaluate the physical, chemical, and biological characteristics of streams relative to environmental settings. Sampling designs for these components coordinate sampling of varying intensity and scope at common sites. The glossary at the front of this report includes brief definitions of the NAWQA study components, indicated throughout the report with capital first letters, and other key terms.

This report describes standard methods for collecting and processing water-column samples from streams as part of the Occurrence and Distribution Assessment component of the NAWQA program. Complimentary methods and procedures are described for collecting and processing biological tissues (Crawford and Luoma, 1992; Meador and others, 1993) and bed sediments (Shelton and Capel, 1994). The methods and techniques described in this report are intended to enable investigators to meet the specific goals of the NAWQA program and are oriented to specific USGS equipment, practices, and support facilities. However, they also can be adapted for use by other Federal and state agencies, as well as by other programs of the USGS.

The procedures described conform to methods presented in the USGS Techniques of Water-Resources Investigations (TWRI) series and in the technical memorandums of the Office of Water Quality (OWQ) and the Office of Surface Water (OSW) of the USGS (see appendix A). The procedures are based, in part, on guidelines released by the OWQ and on a field manual prepared by M.A. Sylvester and others of the U.S. Geological Survey (see appendix B). New material has been added for selected procedures, and some guidelines have been modified to conform with the NAWQA Study-Unit design guidelines. The development of new and improved field techniques is a continuing process; therefore, this field guide will require periodic updating. If these updates outline a different or improved procedure, investigators in each Study Unit will evaluate the effect on the resulting data. Compatibility with previously collected data is essential for the duration of each project.

Trade names used in connection with equipment or supplies do not constitute an endorsement of the product. References are made throughout this document to the U.S. Geological Suvey's National Water Quality Laboratory (NWQL); Quality Water Service Unit at Ocala, Florida (OCALA); and the Hydrologic Instrumentation Facility (HIF). 


\section{OVERVIEW OF WATER-COLUMN STUDY DESIGN}

Water-Column Studies in NAWQA focus on assessing physical and chemical characteristics of stream water, including suspended sediment, dissolved solids, major ions and metals, nutrients, organic carbon, and dissolved pesticides, and on relating these characteristics to hydrologic conditions, sources, and transport. The sampling designs for Water-Column Studies rely on coordinated sampling of varying intensity and scope at two general types of sites, Integrator Sites and Indicator Sites. Integrator Sites are chosen to represent water-quality conditions of streams and rivers in heterogeneous large basins that often are affected by complex combinations of land-use settings, point sources, and natural influences. Indicator Sites, in contrast, are chosen to represent water-quality conditions of streams in relatively homogeneous and usually smaller basins associated with specific individual environmental settings (for example, a particular combination of land-use and geological setting).

Water-column conditions are assessed by three primary sampling strategies employed at the selected Integrator and Indicator Sites:

1. Basic Fixed-Site assessments characterize the spatial and temporal distribution of general waterquality and constituent transport in relation to hydrologic conditions and contaminant sources;

2. Intensive Fixed-Site assessments characterize seasonal and short-term temporal variability of general water quality and constituent transport and determine the occurrence and seasonal patterns in concentrations and transport of dissolved pesticides; and

3. Synoptic studies are investigations of the geographic distribution of selected water-quality characteristics in greater detail during specific seasons and in relation to sources.

Site choices and sampling strategies for Basic Fixed Sites and Intensive Fixed Sites are particularly important to the success of the stream-water design for national water-quality assessment because in this part of the study design all components are integrated by a nationally consistent strategy in all Study Units. The focus of this report is on field procedures for collecting and processing samples from Basic Fixed Sites and Intensive Fixed Sites.

Each Study Unit typically has three to five integrator Basic Fixed Sites and four to eight indicator Basic Fixed Sites. Intensive Fixed Sites usually are composed of one or two Integrator Sites and one to four Indicator Sites. Samples are collected from each site at fixed intervals and at extreme flows. The analytical strategy for samples collected at Basic Fixed Sites is summarized in table 1; the strategy for samples collected at Intensive Fixed Sites is the same, but with the addition of laboratory analyses of dissolved pesticides (table 2). 
Table 1. Analytical strategy for Basic Fixed Sites

\section{Field measurements}

Dissolved oxygen

$\mathrm{pH}$ and Alkalinity

Specific conductance (hourly or daily if local conditions require)

Temperature (hourly for 1 year)

Laboratory analyses

\section{Suspended sediment}

\section{Major constituents:}

Dissolved solids

Major ions and metals:

Calcium

Chloride

Fluoride

Iron

Magnesium

Manganese

Potassium

Silica

Sodium

Sulfate

Nutrients

Nitrogen:

Total

Total dissolved

Ammonia

Nitrite

Nitrate

Phosphorus:

Total

Total dissolved

Ortho

\section{Organic carbon:}

Suspended

Dissolved 
Table 2. Analytical strategy for Intensive Fixed Sites in addition to the Basic Fixed Site analyses

\section{Field measurements}

Specific conductance (hourly or daily for 1 year)

\begin{tabular}{|c|c|c|c|}
\hline & Laboratory analyses: & d pesticides & \\
\hline $\begin{array}{l}\text { Amides: } \\
\text { Alachlor } \\
\text { Metolachlor }\end{array}$ & $\begin{array}{l}\text { Napropamide } \\
\text { Pronamide }\end{array}$ & $\begin{array}{l}\text { Propachlor } \\
\text { Propanil }\end{array}$ & \\
\hline $\begin{array}{l}\text { Carbamates: } \\
\text { Aldicarb } \\
\text { Aldicarb sulfone } \\
\text { Aldicarb sulfoxide } \\
\text { Butylate } \\
\text { Carbaryl }\end{array}$ & $\begin{array}{l}\text { Carbofuran } \\
\text { Carbofuran, 3-Hydroxy } \\
\text { EPTC } \\
\text { Methiocarb } \\
\text { Methomyl }\end{array}$ & $\begin{array}{l}\text { Molinate } \\
\text { Oxamyi } \\
\text { Pebulate } \\
\text { Propham } \\
\text { Propoxure }\end{array}$ & $\begin{array}{l}\text { Thiobencarb } \\
\text { Triallate }\end{array}$ \\
\hline $\begin{array}{l}\text { Chloropheoxy herbicides: } \\
\text { 2,4-D (acid) } \\
\text { Dichlorprop (2,4-DP) }\end{array}$ & $\begin{array}{l}\text { 2,4-DB } \\
\text { MCPA }\end{array}$ & $\begin{array}{l}\text { MCPB } \\
\text { Silvex }(2,4,5-T P)\end{array}$ & $\begin{array}{l}2,4,5-\mathrm{T} \\
\text { Triclopyr }\end{array}$ \\
\hline $\begin{array}{l}\text { Dinitroanalins: } \\
\text { Benfluralin } \\
\text { Ethafluralin }\end{array}$ & $\begin{array}{l}\text { Oryzalin } \\
\text { Pendimethalin }\end{array}$ & Trifluralin & \\
\hline $\begin{array}{l}\text { Organochlorines: } \\
\text { Chlorothalonil } \\
\text { Dacthal (DCPA) }\end{array}$ & $\begin{array}{l}\text { Decthal (mono acid) } \\
p, p^{\prime}-\mathrm{DDE}\end{array}$ & $\begin{array}{l}\text { Dichlobenil } \\
\text { Dieldrin }\end{array}$ & $\begin{array}{l}\text { alpha-HCH } \\
\text { gamma-HCH }\end{array}$ \\
\hline $\begin{array}{l}\text { Organophosphates: } \\
\text { Azinphos-methyl } \\
\text { Chlorpyrifos } \\
\text { Diazinon }\end{array}$ & $\begin{array}{l}\text { Dimethoate } \\
\text { Disulfoton } \\
\text { Ethoprop }\end{array}$ & $\begin{array}{l}\text { Fonofos } \\
\text { Malathion } \\
\text { Methyl parathion }\end{array}$ & $\begin{array}{l}\text { Parathion } \\
\text { Phorate } \\
\text { Terbufos }\end{array}$ \\
\hline $\begin{array}{l}\text { Pyrethroids: } \\
\text { cis-Permethrin }\end{array}$ & & & \\
\hline $\begin{array}{l}\text { Triazine herbicides: } \\
\text { Atrazine } \\
\text { Atrazine, desethyl }\end{array}$ & $\begin{array}{l}\text { Cyanazine } \\
\text { Metribuzin }\end{array}$ & $\begin{array}{l}\text { Prometon } \\
\text { Simazine }\end{array}$ & \\
\hline $\begin{array}{l}\text { Uracils: } \\
\text { Bromacil }\end{array}$ & Terbacil & & \\
\hline $\begin{array}{l}\text { Ureas: } \\
\text { Fenuron } \\
\text { Diuron }\end{array}$ & $\begin{array}{l}\text { Fluometuron } \\
\text { Linuron }\end{array}$ & $\begin{array}{l}\text { Neburon } \\
\text { Tebuthiuron }\end{array}$ & \\
\hline $\begin{array}{l}\text { Miscellaneous: } \\
\text { Actifluorfen } \\
\text { Bentazon } \\
\text { Bromoxynil } \\
\text { Chloramben }\end{array}$ & $\begin{array}{l}\text { Clopyralid } \\
\text { Dicamba } \\
\text { 2,6-Diethylanaline } \\
\text { Dinoseb }\end{array}$ & $\begin{array}{l}\text { DNOC } \\
\text { Esfenvalerate } \\
\text { 1-Napthol } \\
\text { Norflurazon }\end{array}$ & $\begin{array}{l}\text { Picloram } \\
\text { Propargite }\end{array}$ \\
\hline
\end{tabular}




\section{PREPARATION FOR SAMPLE COLLECTION}

\section{SITE SELECTION}

All Basic Fixed Sites and Intensive Fixed Sites should be at or near streamflow gaging stations because stream discharges associated with chemical-constituent concentrations are needed to compute constituent transport and to evaluate relations between streamflow and water-quality characteristics (Gilliom and others, 1994). The sample collection site should not be more than a few hundred feet from the site of the gage, unless no appreciable inflow is between the sampling site and the gaging station.

Criteria for selecting a site for water-sample collection are different from those for selecting a site for measurement of streamflow. Greater accuracy in computing constituent transport may be attained by selecting a cross section based on sediment-transport and mixing characteristics rather than hydraulic measurements such as velocity. Collection sites should be located in relatively straight channel reaches where the flow is uniform. Collecting samples directly in a ripple or from ponded or sluggish water should be avoided. Sites upstream or downstream of confluences or point sources also should be avoided to minimize problems caused by backwater effects or poorly mixed flows. Samples collected directly downstream from a bridge can be contaminated from the bridge structure or runoff from the road surface.

\section{SAMPLING EQUIPMENT}

The standard samplers used in the NAWQA program for collecting water samples include the DH-81, D-77 TM, D-77 Bag, and weighted- and open-bottle samplers with Teflon or glass components. These samplers will collect representative water-chemistry samples in most stream environments; however, their limitations must be carefully considered when collecting isokinetic samples (see OSW technical memorandum 94.05 , appendix A). For a more thorough discussion of the proper use of each sampler, see the "Collection Methods" section.

Knowledgeable, independent field judgement is essential for collecting a sample representative of the stream chemistry. The following information should be considered before making a decision on which sampler to use:

-Understand the sampling purpose and the desired results,

-Evaluate the stream conditions (depth, velocity, and distribution),

-Know the limits and consequences of the available samplers, and

-Decide which sampler and procedure will give the best results for the stream conditions.

Whichever sampler and procedure is used, document the stream conditions, sampler limitations, and method used. The equipment and supplies used in the collection procedures are listed in table 3. 
Table 3. List of equipment and supplies for sampling and processing stream-water samples

[Sources for some items are listed to maintain quality standards or when volume discounts are available. HIF, Hydrologic Instrumentation Facility; OCALA, Quality Water Service Unit at Ocala, Florida; DIW, deionized water; NWQL, National Water Quality Laboratory; FMI, Fluid Metering Incorporated; OWQ, Office of Water Quality; ASTM, American Society for Testing and Materials; DO, dissolved oxygen; SPE, solid-phase extraction. $\mathrm{ft}$, foot; gal, gallon; $\mathrm{g} / \mathrm{L}$, gram per liter; in. inch; $\mathrm{L}$, liter; $\mathrm{mL}$, milliliter; $\mathrm{mm}$, millimeter; $\mu \mathrm{m}$, micrometer; $\mu \mathrm{S} / \mathrm{cm}$, microsiemens per centimeter at 25 degrees Celsius]

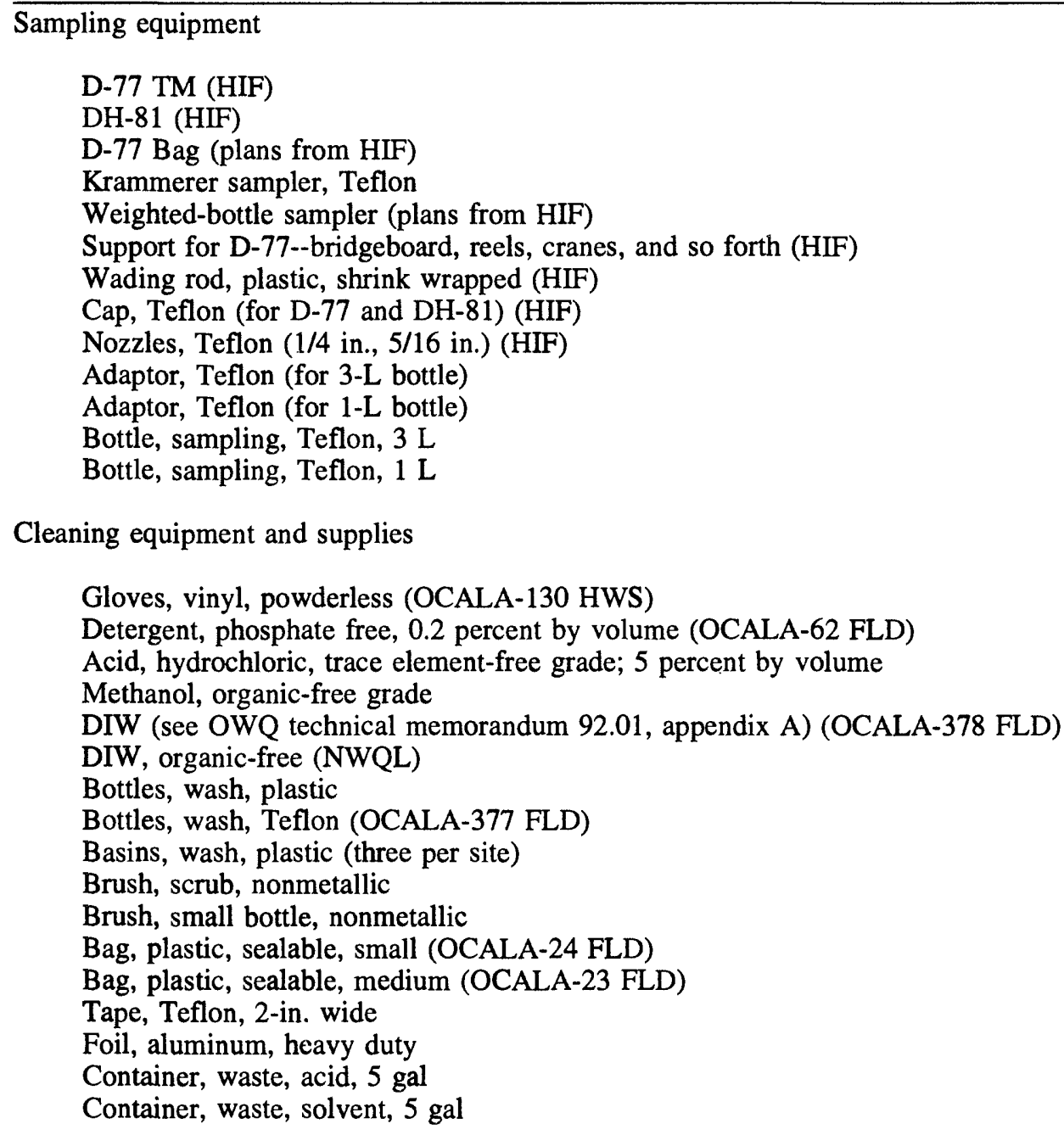

Processing equipment and supplies

Splitting

Cone splitter, Teflon (decaport) with fitting (Geotech-0901)

Tubing, Teflon, $1 / 4$ in. (for cone splitter)

Chamber, processing (from plans)

Bottles for splitting, amber glass, prebaked, $1 \mathrm{~L}$ (NWQL)

Botties, sediment, plastic, 1 L (NWQL)

Bottles, subsample, (NWQL)

Bags, plastic, large clear (for processing chamber)

\section{Filtration-inorganic constituents}

Chamber, processing (plans from HIF)

Pump, peristaltic, head (OCALA-20 FLD)

Pump, peristaltic, motor assembly (OCALA-20 FLD) 
Table 3. List of equipment and supplies for sampling and processing stream-water samples--Continued

Filtration-inorganic constituents--Continued

Tubing, pump, Tygon or silicon

Forceps, nonmetallic

Cartridges, capsule filter, $0.45 \mu \mathrm{m}$ (OCALA-398 FLD)

Gloves, vinyl, powderless, (OCALA-130 HWS)

Bags, plastic, large clear (for processing chamber)

Battery, 12-volt hotshot, dry cell (OCALA-82 FLD)

Bottles, plastic, brown, $125 \mathrm{~mL}$ (NWQL)

Bottles, plastic, clear, $250 \mathrm{~mL}$ (NWQL)

Bottles, plastic, clear, $500 \mathrm{~mL}$ (NWQL)

Filtration-organic carbons

Filter assemble, pressure barrel, stainless steel, $500 \mathrm{~mL}$

Hand vacuum/pressure pump (OCALA-361 FLD)

Tubing, Tygon, $1 / 4$ in. by $5 \mathrm{ft}$

Forceps, stainless steel, (OCALA-347 BACT)

Filters, silver, $47 \mathrm{~mm}$ by $0.45 \mu \mathrm{m}$ (OCALA-68 FLD)

Cylinder, graduated, glass, $100 \mathrm{~mL}$

Cylinder, graduated, glass, $250 \mathrm{~mL}$

Bottle, sample, amber glass, prebaked, $250 \mathrm{~mL}$ (NWQL)

Bottle, analyses, amber glass, prebaked, $125 \mathrm{~mL}$ (NWQL)

Petri dishes (OCALA-5 BACT)

DIW, organic-free (NWQL)

Bag, plastic, sealable (OCALA-24 FLD)

Gloves, vinyl, powderless (OCALA-130 HWS)

Filtration-organic compounds (kit available OCALA-386 FLD)

Balance, portable, 6,000 by 1.0 grams (Ohaus-CT6000)

Pump, metering, 1/8-in. adapters (FMI-QB-1-CSC)

Pump, metering, fitting (FMI-RHB-0-CKC)

Filter support, aluminum, $147 \mathrm{~mm}$, fittings (Geotech-0860)

Tubing, Teflon, corrugated, $1 / 4$ in. by $5 \mathrm{ft}$

Tubing, Teflon, $1 / 8 \mathrm{in}$. by $10 \mathrm{ft}$

Bottles, wash, Teflon, $250 \mathrm{~mL}$ (OCALA-377 FLD)

Dispenser, bottle top, bottle $(1.0$ by $10 \mathrm{~mL})$

Valves, Teflon, flow control, (NWQL)

Cylinder, graduated, glass, $25 \mathrm{~mL}$

Cylinder, graduated, glass, $50 \mathrm{~mL}$

Forceps, stainless steel (OCALA-347 BACT)

Syringe, disposable, $50 \mathrm{~mL}$ (OCALA-105 FLD)

Micropipette, fixed volume, $100 \mathrm{~mL}$

Fitting, union, adaptor for SPE cartridge (NWQL)

Filters, glassfiber, prebaked, (147 mm by $0.7 \mu \mathrm{m})$ (OCALA-375 FLD)

Bottles, amber glass, prebaked, 1,000 mL (NWQL)

Methanol, organic-free grade

DIW, organic free (NWQL)

Spike mixture, vials, $4 \mathrm{~mL}$ (NWQL)

SPE cartridges, analytichen C-18 (NWQL)

SPE cartridges, carbopak-B (NWQL)

Bores, glass, disposable, for micropipette (NWQL)

Surrogate mixture, vials, $200 \mathrm{~mL}$ (NWQL)

Acid, ascorbic, $10 \mathrm{~g} / \mathrm{L}$

Beaker, plastic, $1,000 \mathrm{~mL}$

Foil, aluminum, heavy duty

Gloves, vinyl, powderless (OCALA-130 HWS)

Battery, hotshot, 12 volt, dry cell (OCALA 82 FLD) 
Table 3. List of equipment and supplies for sampling and processing stream-water samples--Continued

Preservation

Chamber, preservation (2) (from plans)

Gloves, vinyl, powderless (OCALA-130 HWS)

Nitric acid, ampules (NWQL)

Nitric acid/potassium dichromate, ampules (NWQL)

Sleeves, foam (OCALA-136 FLD, 358 FLD)

Ice

Field analyses equipment and supplies

Thermistor, electronic thermometer

Thermometer (ASTM)

Meter, specific conductance, electrode

Meter, $\mathrm{pH}$

Electrode, $\mathrm{pH}$, combination, liquid filled (OCALA-351 FLD)

Meter, dissolved oxygen

Probe, dissolved oxygen (OCALA-116 FLD)

Standards, specific conductance, 100 to $50,000 \mu \mathrm{S} / \mathrm{cm}$ (OCALA-42 FLD--54 FLD)

Buffers, pH 4 (OCALA-123 FLD)

Buffers, pH 7 (OCALA-125 FLD)

Buffers, pH 10 (OCALA-127 FLD)

Membrane repair kit, DO (OCALA-115 FLD)

Solution, zero, DO (OCALA-119 FLD)

Titrator, digital (OCALA-145 FLD)

Acid, sulphric, titrator cartridge (OCALA-142 FLD, 143 FLD)

Stirrer, magnetic, portable (OCALA-356 FLD)

Stirring bar, Teflon, magnetic

Beakers, glass, $100 \mathrm{~mL}$

Beakers, glass, $250 \mathrm{~mL}$

Beakers, glass, $500 \mathrm{~mL}$

Barometer

Chamber, air-calibration (Wand)

Pipet, volumetric, $50 \mathrm{~mL}$

Pipet, volumetric, $100 \mathrm{~mL}$

Bottle, wide mouth, plastic, $1,000 \mathrm{~mL}$

Meter logs

Tissues, laboratory

DIW (see OWQ technical memorandum 92.01, appendix A) (OCALA-378 FLD)

Miscellaneous equipment and supplies

Boots, hip

Waders, chest

Tools

Kit, first aid

Kit, highway emergency

Forms, field documentation (OWQ)

Forms, analytical request (NWQL)

Coolers, shipping, $1 \mathrm{gal}$

Coolers, shipping, $5 \mathrm{gal}$

Bottle tags (OCALA-84 FLD)

Ropes, nylon, 1/4 and 1/2 in. (OCALA-84 FLD)

Pens, marking, permanent, (OCALA-77 FLD) 
The DH-81 or an open-bottle sampler should be used when streamflow conditions permit the stream to be waded. The DH-81 sampler consists of a polypropylene collar screwed onto a plastic-coated wading rod. The collar is notched to accept the D-77-type Teflon cap and nozzle assembly, which is locked in the sampling position. A 1- or 3-L Teflon bottle can be used with the appropriate cap-bottle adaptor. The DH-81 can use a 1/4- or 5/16-in. Teflon nozzle. An open-bottle sampler is the simplest means of collecting a water sample. An uncapped glass or Teflon bottle is submerged in the stream by hand (see "Weighted Bottle" section).

\section{SUSPENDED SAMPLERS}

The following suspended samplers can collect depth-integrated samples when used within their recommended limits. These samplers are suspended from, and lowered into, the stream by a rope or cable and usually require the use of additional equipment because of their weight (see "Support Equipment" section).

\section{D-77 TM}

This 75-lb sampler (epoxy coated to prevent trace-element contamination) collects large-volume (nearly $3 \mathrm{~L}$ ) samples. This sampler is approved for flow velocities from 2.0 to $8.0 \mathrm{ft} / \mathrm{s}$, though some instability has been noted in turbulent flow velocities exceeding $6.0 \mathrm{ft} / \mathrm{s}$. Depth limitations of the D-77 TM sampler are dependent on a combination of depth and velocity, preventing the sampler from overfilling when used with the recommended transit rate and the required nozzles. The recommended operating depth is between 3 and $15 \mathrm{ft}$. The Teflon cap has standard Mason-jar threads to make it compatible with a large glass sample bottle. The older Teflon caps require a Teflon cap-bottle adaptor when using the 3-L bottle. Caps purchased after July 1994 will not require the use of the cap-bottle adaptor. The recommended nozzle sizes for the D-77 TM sampler is 1/4- and 5/16-in. and must be made of Teflon. However, in extremely high flows or when sampling depths cause the 3-L sample bottle to overfill in a single vertical, a 3/16-in. nozzle can be used. This sampler was counterweighted during manufacturing for specific-sample bottle use. Always check the balance to ensure that the sampler is level when fitted with an empty bottle, cap, adapter, and nozzle.

\section{D-77 Bag}

This sampler is designed to collect large-volume (up to $8 \mathrm{~L}$ ) samples. Counterweights suspended below this sampler allow for sample collection in streams where depths exceed the limits of the D-77 TM and where the combination of depth and velocity cause other samplers to overfill. The sampler uses the standard D-77 Teflon cap and nozzles. Teflon bags attached to the cap are held in place by a large rigid botile, a frame, or both. The bag enables this sampler to collect larger volume samples. Prototypes currently are being tested. It is not known if the sampler collects samples isokinetically; the pressure inside the nozzle must be greater then the pressure outside the nozzle for the bag to fill. This sampler is difficult to use because of the collapsible bag and the sediment is hard to remove. Its use is not recommended when velocities are less than $2 \mathrm{ft} / \mathrm{s}$ and should be used only when the D-77 TM is inappropriate. Plans and operating instructions for this sampler are available from HIF. Document the use of this sampler.

\section{Under Ice}

Under-ice samplers that use the D-77 bottle, cap, and nozzle are currently being developed. The sampler is base 1 on the DH-81 design and pivots into a vertical position, allowing it to go through an 8-in. ice hole. Contact the HIF for more information. Until this sampler is available, a DH-81 or a weighted bottle sampler should be used. A hand-held ice chisel should be used when making holes in the ice to avoid leaving residual contamination from the power equipment. 


\section{Welghted bottle}

A weighted bottle is a simple way to collect a water sample in slow moving streams. Weights are added to an uncapped glass or Teflon bottle suspended from a rope for depth sampling. The sampler can be handmade (plans are available from HIF) and consists of a plastic basket or frame with a weight attached that holds a specific-size bottle. These samplers do not collect a depth-integrated, isokinetic sample; the sampling depth is mainly dependent on the capacity and inside diameter of the bottle opening. However, a representative sample usually can be collected from shallow streams when the suspended sediment is distributed uniformly in the vertical and the velocity is less than $2.0 \mathrm{ft} / \mathrm{s}$. These samplers are most appropriate where differences in water-quality distribution within the cross section of the stream are insignificant.

A Teflon Kemmerer sampler can be used to composite depth-integrated samples from various depths. A Kemmerer sampler is a 4- by 18-in. tube with end caps that close by means of a messenger and entrap a 4.2-L water sample inside. This sampler collects a point sample from a specific depth. Composite several point samples from one vertical for a depth-integrated sample.

NOTE: When suspending a weighted-bottle sampler, use a single-filament line or rope (for example, a synthetic fiber such as nylon or Kevlar). Attach the line to the corner of the sampler to hold the bottle at a slight angle to avoid dripping river water from the line into the sample bottle.

\section{SUPPORT EQUIPMENT}

Some of the equipment used for streamflow monitoring also is used as support equipment for collecting water samples. A discussion of the various types of support equipment is presented in a report by Rantz and others (1982). Great care is needed when using multipurpose equipment for water-quality sampling and sample processing. The clean hands/dirty hands technique outlined in OWQ technical memorandum 94.09 (appendix A) should be followed when using metal support equipment. With this procedure one person (dirty hands) operates the support equipment and another person (clean hands) handles the cleaned collecting equipment.

Many field vehicles are used for more than one purpose (that is, streamflow measurements, gage maintenance, construction, stream sampling, and sample processing). Sample contamination is more likely to occur when multiuse vehicles are used to collect and process water samples. Therefore, it is strongly recommended that all water-quality sampling and processing be restricted to vehicles designed for that purpose. The processing area in the vehicle needs to be free of contaminants, metallic objects, dirt, and oil residue. Separate storage areas for the sampling equipment, acids, and solvents should be available, and the vehicle must be well ventilated. Several specially designed vehicles are currently in use. One example is a truck-mounted laboratory designed for use at the Rocky Mountain Arsenal by USGS personnel in Denver, Colorado.

\section{PROCESSING EQUIPMENT}

The equipment used to prepare and preserve the stream samples for laboratory analyses is specific to the desired results and includes processing chambers, splitters, filtering systems, and preservation chambers. A complete list of processing equipment and supplies is given in table 3.

\section{PROCESSING AND PRESERVATION CHAMBERS}

The use of processing chambers reduces the possibility of contamination and is required during the splitting and filtration processes (see OWQ technical memorandum 94.09, appendix A). Sample preservation must be done inside separate chambers to avoid cross contamination. These processing and preservation chambers are handmade (plans are available from HIF). Generally a 2-by 2-by 2-ft frame is constructed using 1/4-in. polyvinyl chloride (PVC) to support a clear plastic bag, which forms a protective tent to work inside when processing and preserving samples. 
Two types of splitters are available for compositing and splitting, the cone (decaport) and the churn. The cone splitter is a positive pour-through device that composites and splits the sample in one step. A funnel-shaped reservoir receives the sample and directs it into a splitting chamber. The splitting chamber is a solid block with 10 outlet ports (placed at $36^{\circ}$ intervals around the circumference and drilled at $45^{\circ}$ angles) that meet in the center to form an inverted cone. The resulting configuration splits samples into 10 equal subsamples. Tests have shown that the cone splitter can split sample volumes as small as 250-mL into 10 equal subsamples, each subsample volume within an accuracy of 5 percent (see OWQ technical memorandum 80.17, appendix A). Tests of the distribution characteristics of the cone splitter (Capel and Nacionales, 1993) indicate that, even with a slight difference in the volume of the subsamples, the relative percent of sediment mass to sample volumes are within 3 percent at each port, and the particle-size distribution of the finer than coarse-sand fraction is within 5 percent.

Tests indicate that the churn splitter does not produce equivalent subsamples for sediments coarser than $63 \mathrm{~mm}$. There is concern that a metal spring in the spigot may contaminate the samples for traceelement analyses (see OWQ technical memorandum 94.09, appendix A). The churn should be used only as a compositing vessel for dissolved inorganic samples withdrawn from the top (see OWQ technical memorandum 94.13 , appendix A). The churn is limited in sample volume and currently is available only in a plastic version.

Based on all available information, the Telfon cone splitter is the best available equipment for compositing and splitting whole water samples for analyses of major ions, nutrients, trace elements, pesticides, and sediment. It is presently the only alternative for splitting pesticide and sediment samples. However, when methanol is used for cleaning the cone, it is not suitable for splitting samples for total organic compounds (TOC), dissolved organic compounds (DOC), and volatile organic compounds (VOC). Those samples must be collected separately, directly from the stream, to avoid contamination. The churn is suitable for compositing dissolved inorganic constituent samples, but NAWQA studies seldom sample for these constituents in isolation. Thus, for the multipurpose needs of NAWQA, the use of the Teflon cone splitter is required.

\section{FILTER SYSTEMS}

Some samples collected for inorganic constituents and most samples for organic constituents must be filtered in the field. Filtration equipment and procedures vary slightly depending on the type of constituents the filtration process is intended to isolate. The equipment basically consists of a variable-speed, battery-operated pump fitted with a peristaltic pump head or a metering pump that forces the sample through Tygon, silicon, or Teflon tubing into a filter assembly. A capsule filter system with an effective pore size of $0.45 \mu \mathrm{m}$ is used for filtering inorganic constituents. The filter type used to process the dissolved organic-carbon samples has the same pore size, but uses a stainless-steel pressure filter unit to hold a $47-\mathrm{mm}$-diameter silver filter. The plate filter used for organic-compound analyses is $142 \mathrm{~mm}$ in diameter and is made of glass fiber with a pore size of $0.7 \mu \mathrm{m}$. 


\section{EQUIPMENT CLEANING}

INORGANIC CONSTITUENTS AND ORGANIC COMPOUNDS

The collecting and processing equipment are soaked in dilute phosphate-free detergent solution, rinsed with tap water, soaked in 5.0 percent hydrochloric acid $(\mathrm{HCl})$, rinsed with deionized water (DIW), rinsed with methanol, and then air dried prior to each field trip and between sites (see OWQ technical memorandum 94.09, appendix A). Detergents, methanol, and acids should be used with care to avoid possible contamination of the sample by their residue. A thorough native-water rinse is required at each field site before sampling to remove any remaining cleaning agents and equilibrate the equipment to the sampling conditions. A list of the supplies needed for equipment cleaning is given in table 3 , and details on procedures are outlined below.

The sampler bottle, cap and nozzle, cone splitter, churn splitter, filter support, pumphead, tubing, and any other equipment (except the aluminum filter support used for organic-compound filtering) that will contact the sample are cleaned prior to each field trip and between sites as follows:

1. Disassemble (if necessary) wearing vinyl gloves.

2. Soak for 30 minutes in a 0.2-percent solution of phosphate-free detergent and scrub with a nonmetallic brush. Use a small bottle brush for the cone-splitter parts.

3. Change gloves and rinse throughly with warm tap water to remove all soap residue.

NOTE: FOR EQUIPMENT USED EXCLUSIVELY FOR ORGANIC-COMPOUND PROCESSING OMIT STEPS 4 AND 5.

4. Soak for 30 minutes in a solution of 5.0-percent hydrochloric acid. Swirling the equipment in the acid solution will adequately desorb any metals not removed during the washing process. The used acid/water solution should be placed in a waste container for proper disposal (see OWQ technical memorandum 94.06, appendix A).

5. Change gloves and rinse three times with DIW water.

NOTE: IF ORGANIC-COMPOUNDS SAMPLES ARE NOT COLLECTED, OMIT STEPS 6 AND 7.

6. Rinse the equipment used for the collection of samples for organic-compound analyses with a minimum amount of methanol. The used methanol should be placed in a waste container for proper disposal (see OWQ technical memorandum 94.07, appendix A).

7. Allow to air dry.

8. Protect areas of the equipment that will contact the sample with Teflon tape and place in a sealable plastic bag for storage and transport.

9. Rinse sampling and splitting equipment at the site with 2 to $3 \mathrm{~L}$ of native water before sampling.

10. Rinse sampling and splitting equipment with DIW immediately after each use.

\section{ORGANIC CARBON}

Equipment used for filtering the organic-carbon samples should be baked at $450^{\circ} \mathrm{C}$ for 2 hours or cleaned using organic-free DIW and aggressive scrubbing. USE NO DETERGENT OR METHANOL as routine cleaning agents. Protect and keep equipment away from any procedure using methanol (even the vapors could contaminate the equipment). If this equipment is contaminated and requires additional cleaning, scrub with a 0.1-percent solution of phosphate free detergent, then soak and rinse several times with large volumes of organic-free DIW. 


\section{COLLECTION METHODS}

Proper sampling techniques must be used to ensure that a sample is representative of the flow in the cross section. A discussion of sampling techniques is presented in reports by Edwards and Glysson (1988) and Ward and Hair (1990). Some aspects of sampling also are included in other USGS TWRIs, OWQ technical memorandums (see list of references, appendix A), and in the recommended methods for waterdata acquisition (U.S. Geological Survey, 1978). A discharge measurement should be made prior to sampling if a rated discharge is not available.

Collect samples at the same cross section throughout the period of record, if possible. This will eliminate many of the potential problems that might arise during the interpretation of water-quality data. For example, measuring streamflow in a pool and sampling in a nearby riffle might prevent use of the hydraulic information to compute constituent transport. Sand may move through the pool as bedload and through the riffle as suspended load. This does not mean that the same section used during the low-water wading stage must be used during higher stages that require the use of a bridge or cableway. However, the flow characteristics at the different cross sections can result in incomparable data if the cross sections are not located near each other or in the same flow regime.

The number of verticals sampled at a site should be based primarily on the requirement to collect a sample representative of cross-sectional chemistry and secondarily to obtain the volume of the sample required. Samples usually should be collected using a standard multivertical depth-integrating method to obtain the most representative isokinetic sample possible. However, abbreviated sampling methods (that is, weighted-bottle or dip sample) are sometimes the best procedures for collecting a sample representative of the stream chemistry. Single vertical, dip, or other point-sampling methods can be used when the cross-sectional transport characteristics of the site are documented adequately or extreme flow conditions exist that preclude the use of standard methods. The Telfon bag sample might not provide a sample representative of stream hydrodynamics; however, it can collect a representative noncontaminated sample in deep or fast moving streams. Considering the limits of the other samplers, the D-77 TM might be the most appropriate sampler under many conditions, even when used beyond its limits. All samples collected by nonstandard methods should be checked periodically against standard cross-sectional samples to develop correction coefficients for the data.

Prior to initial sampling at a site, and again 3 to 4 times per year, obtain a stream profile of field measurements (velocities, specific conductance, temperature, $\mathrm{pH}$, and dissolved oxygen). Record observations from several verticals and depths in the cross section to determine the uniformity of these characteristics. These measurements should be used as guides in selecting an adequate number of verticals for obtaining a representative sample.

The vertical transit rate and operational depth of each sampler is a function of the stream velocity, sample-container volume, and nozzle size. The following chart gives the recommended vertical transit rates and the maximum depths for isokinetic sampling based on samplers and nozzles. Specific limitations of the samplers are in OSW technical memorandum 94.05 (see appendix A).

\begin{tabular}{lccc}
\hline Sampler & $\begin{array}{l}\text { Nozzle } \\
\text { diameter } \\
\text { (inches) }\end{array}$ & Ratio & $\begin{array}{c}\text { Depth } \\
\text { (feet) }\end{array}$ \\
\hline DH-81 & $1 / 4$ & 0.4 & 9 \\
DH-81 & $5 / 16$ & 0.4 & 6 \\
D-77 TM & $1 / 4$ & 0.1 & 15 \\
D-77 TM & $5 / 16$ & 0.2 & 15 \\
\hline
\end{tabular}

Stream velocity $\times$ ratio $=$ maximum vertical transit rate 
Because of the limits of existing samplers to collect an isokinetic sample, considerable independent judgement is necessary to collect a sample representative of the stream chemistry. The entire stream cross section must be represented in the final sample to avoid the potential loss of pollutants that might be seeping from the streambanks or streambed. Therefore, it might be necessary to increase the vertical transit rate or use a smaller nozzle to avoid overfilling the sampler when representing the entire stream depth. A weighted-bottle or D-77 bag sampler also might be used. Figure 1 illustrates the recommended sampler options for the NAWQA program based on stream depth and velocity.

Intermittent streams require special consideration because little opportunity exists to study conditions or sample in detail prior to a flow event. Rapidly changing stage, discharge, and constituent concentrations dictate that abbreviated sampling schemes and techniques be planned carefully in advance to ensure that the most representative samples possible are obtained.

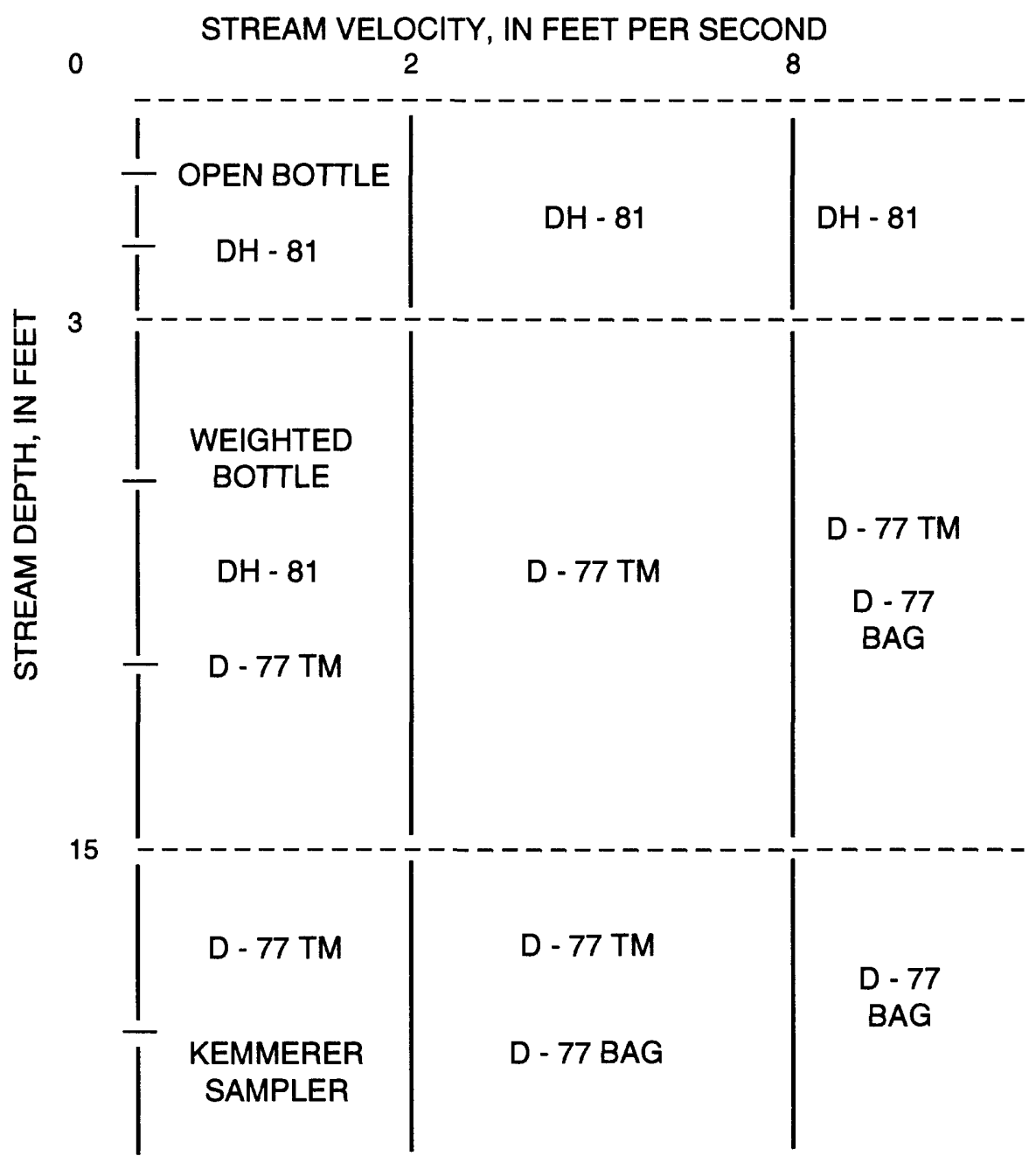

Figure 1. Schematic of suggested water-quality samplers for various stream regimes. 


\section{EQUAL-WIDTH-INCREMENT SAMPLING}

The equal-width-increment (EWI) sampling method is the recommended procedure for NAWQA. The EWI method must be used during any sampling condition where a discharge measurement is not made before sampling; where the period of discharge record is insufficient to develop stage-discharge rating curves; where the streambed material is mobile, resulting in a poor stage-discharge relationship; or where inflow from a tributary is not well mixed in the sampling section. Detailed information on EWI sampling is presented in a report by Edwards and Glysson (1988).

The EWI method requires equal spacing of a number of verticals across the cross section and an equal transit rate, both upward and downward, in all verticals. The stream width is divided into a number of equal-width intervals; the number of intervals is dependent on results of water-quality profiles, uniformity of sediment distribution, channel width, and the depth and velocity distribution across the stream. Use 5 to 10 increments for cross sections less than $5 \mathrm{ft}$ wide and a minimum of 10 increments in streams 5 $\mathrm{ft}$ wide or greater. A maximum of 20 increments should be used in extremely wide, shallow cross sections. The sample verticals should be spaced at least 6 in. apart.

Samples from several verticals can be accumulated in the same bottle. Do not allow the bottle to overfill because secondary circulation and enrichment of heavy particles can occur and bias the sample. Empty the bottle and resample the EWI stations if overfilling should occur.

The same transit rate must be used for all verticals. When additional verticals cannot be sampled without overfilling the bottle, empty the bottle directly into the cone splitter or use another bottle and continue sampling in the same manner until all of the verticals have been sampled. Transverse the EWI verticals as many times as necessary to ensure collection of the volume of sample required for analysis. When more than one traverse of each vertical is required, the composited cross-sectional sample will be proportional to the flow if each EWI vertical is transversed an equal number of times.

\section{EQUAL-DISCHARGE-INCREMENT SAMPLING}

The equal-discharge-increment (EDI) sampling method can be used on large streams only if the streamflow distribution within the cross section is known; that is, a discharge measurement is made prior to sampling. This method is not preferred, however, because it limits the number of verticals and could misrepresent a stream with stratified chemical characteristics. A discussion of this method is in a report by Edwards and Glysson (1988).

\section{NONSTANDARD SAMPLING}

Most samples collected for NAWQA are obtained by the depth-integrating samplers, DH-81 and D-77 TM. The quality of samples collected using nonstandard methods is likely to be inferior to those obtained with depth-integrating samplers (see the "Sampling Equipment" section). Identify all instances of nonstandard sampling in the field notes. Below are instances where other samplers or methods might be needed.

\section{ORGANIC-CARBON SAMPLING}

Special care must be taken when collecting samples for organic carbon analyses because the use of methanol as a cleaning agent will contaminate the DOC sample. Collect the sample directly into a baked 250-mL amber glass bottle using a weighted-bottle or open-bottle sampler at a single midstream vertical to avoid contamination from equipment or cleaning procedures. Because the sample probably will be more representative if the entire vertical is sampled, lower the sampler into the stream as quickly as possible. This compromised nonisokinetic collection procedure, designed to prevent equipment contamination, could affect the integrity of the suspended-organic-carbon (SOC) sample because the suspended sediments are not represented correctly. 


\section{LOW-FLOW SAMPLING}

In very shallow or low-flow water where a depth-integrating sampler cannot be submerged, a representative sample usually can be obtained by immersing a hand-held open bottle (dip sample) in the centroid of flow or at multiple verticals with the mouth of the bottle directed toward the current. A dip sample should never be taken when it is possible to obtain depth-integrated samples. In natural streams when velocity is greater than $1.5 \mathrm{ft} / \mathrm{s}$, suspended sediment normally has a higher concentration near the streambed than near the surface. The bias introduced by dip sampling can be considerable if the sample is analyzed for trace elements or other constituents that can sorb onto sediment particles.

\section{HIGH-FLOW SAMPLING}

If the velocity of the stream is so great that the sampler is pulled downstream and cannot be lowered in the vertical or the combination of depth and velocity cause the sampler to overfill, alternate sampling methods are necessary. Under these conditions, sample with a D-77 bag sampler or exceed the limit of D-77 TM sampler and document the procedure. The number of sampling verticals should be kept to a minimum during periods of storm runoff when the stage is rapidly changing and it is necessary to collect a large number of samples from several locations within a relatively short period of time. Under these conditions, collect the samples at a reduced number of verticals at each site and document the circumstances and number of verticals on the field notes.

\section{SAMPLING FROZEN STREAMS}

During periods of extreme cold when nozzles or air exhausts in samplers freeze up, use a sampler designed for collection under ice (such as described under section, "Sampling Equipment") or collect directly into an open bottle through a hole in the ice.

\section{AUTOMATIC SAMPLERS}

Automatic pumping samplers with a single-fixed intake are sometimes used to collect samples at remote sites or small streams with flashy hydrologic response. Pumped samples must be compared to EWI samples collected over the range of flow conditions at the site. EWI samples are used to develop coefficients for the point samples collected by the automatic pumping sampler. Analyze comparison samples for the same constituents as the pumped samples to determine the relation between the constituent concentrations at the single fixed-intake location and their respective mean concentrations in the cross section. Use this information to select the best location in the channel for the pump intake. Retrieve samples from the automatic sampler at the earliest possible time to reduce the chance of chemical or biological alteration of the sample. Refrigerated Teflon automatic samplers are available to help maintain sample integrity. Flow-composite samples can be obtained by withdrawing a small aliquot of sample from each bottle collected during an event and compositing into a single bottle for analyses.

\section{SAMPLE PROCESSING}

The EWI sampling method produces a composite sample that is representative of flow in a cross section. When sampling for multiple chemical constituents, the sample must be subdivided within a short time after collection into a number of subsamples, each equivalent in concentration of suspended and dissolved constituents. A complete list of the equipment and supplies used in processing water samples (splitting, filtration, and preservation) is given in table 3.

Precautions must be taken to avoid contamination from the atmosphere during the processing procedure. Sample processing equipment should be kept covered (when not dispensing sample), and subsample bottles should be covered or capped. All sample preparation and processing should be done in a field processing chamber or inside a clean field vehicle. 


\section{SPLITING}

The cone splitter is being used as the primary splitter to divide the collected sample into subsamples for inorganic-constituent, organic-constituent, and suspended-sediment analyses. Subsamples for filtered inorganic-constituent, organic-compound, suspended-sediment, and field analyses should be collected from the first set of split samples from the cone splitter. Subsequent splits should be used to collect subsamples for raw (unfiltered) inorganic-constituent analyses. If samples are collected only for dissolved inorganicconstituent analyses, the churn splitter may be used instead of the cone splitter (see OWQ technical memorandum 94.09, appendix A). The plastic churn splitter should not be used for compositing or splitting samples for the analysis of suspended sediment or organic compounds.

Individual samples collected in a D-77 TM sampler can be poured directly into the cone splitter from each vertical, or each time the D-77 bottle is full. Alternatively, the entire sample can be collected in several (three or four) D-77 sample bottles and later poured into the cone splitter. Either method allows the cone splitter to function as both a splitter and compositor. The sample should be well mixed in the D-77 sample bottle when dispensing the composited sample into the cone splitter. Agitate the bottle to resuspend adequately the sediment and pour rapidly into the splitter. Make sure all sediment is removed.

The splitting process is as follows:

1. Set up the cone splitter on a flat, open area. A level splitter is critical to performance. All Teflon tubes should be approximately the same length.

2. Field rinse all sample-collection and splitting equipment with native water. Collect the rinse water near the shore to avoid heavy suspended sediments. Pour rinse water from the D-77 sample bottle through me Teflon cap and nozzle and into the cone splitter. Three 1-L rinses are more effective then one $3-\mathrm{L}$ rinse.

3. Place subsample containers under each outlet tube. The tubes need only extend into the receiving containers far enough to prevent spillage.

4. Cover the reservoir of the cone splitter and seal each port (with Teflon tape) as it enters the subsample bottle to prevent airborne contamination. A large plastic bag should be placed over the splitter and subsample bottles when not in use.

5. Agitate the sample (10 to 15 seconds) in the D-77 bottle to resuspend the sediments. Invert the bottle over the cone splitter reservoir. Sample transfer should be rapid. Maintain a head of water above the standpipe to prevent air from entering the splitting block.

6. Remove subsample containers from cone splitter and cap immediately.

7. An additional split is necessary to obtain the smaller volumes of some required subsamples. Reload splitter ports with the required bottles and pour a subsample from the first set of split samples.

8. Disassemble the cone splitter after completing the sample processing and clean before reuse or storing. 
Below is an example of the splitting technique. Consider that an 8- to 9- $\mathrm{L}$ composite sample must be split to achieve a set of final subsamples as follows:

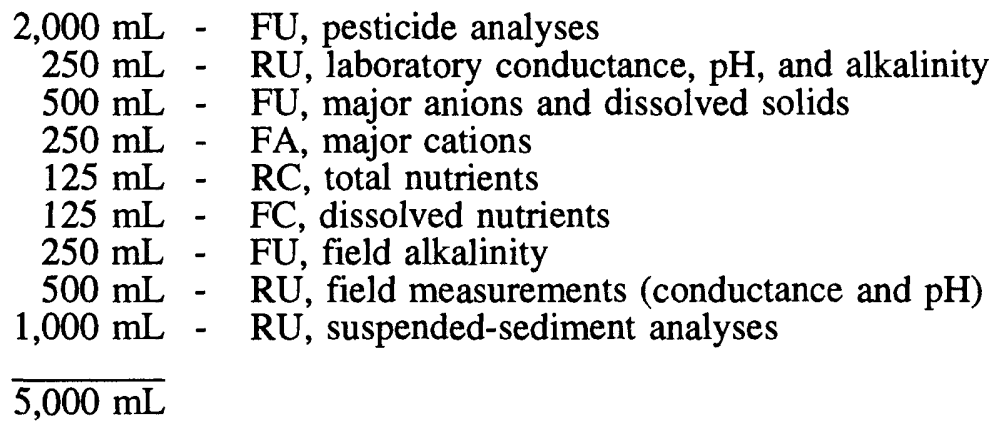

where

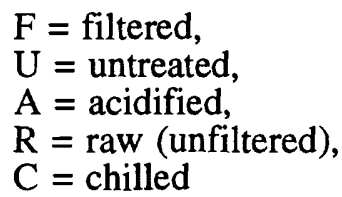

One 1-L bottle under each of the splitter ports will generate a set of subsamples with 800 to $900 \mathrm{~mL}$ in each bottle. If additional volume is desired in the 1-L subsamples, pore one of the subsamples back through the splitter to top off the volume in the remaining 9-L subsamples with an additional 80 to $90 \mathrm{~mL}$. Set aside three of the 1-L bottles for filtering the pesticide samples and save one 1-L bottle for suspended-sediment analyses. Use one 1-L bottle for field measurements of conductance and $\mathrm{pH}$. Two 1-L bottles can be used to filter samples for major ions, nutrients, and field alkalinity. Place a 125-mL bottle for the nutrient sample (RC) under one splitter port and combine two ports into a 250 -mL bottle for the RU sample. Pour one of the 1-L subsamples from the first split through the splitter to fill the second set of subsamples with the approximate volumes. The remaining two 1-L bottles can be used for extra samples or for rinsing the equipment in the filtering process. An example of the first set of subsamples (approximately $850 \mathrm{~mL}$ each) follows:

3 - Pesticides (to be filtered),

2 - Major ions, nutrients, and field alkalinity (to be filtered),

1 - Sediment $(\mathrm{RU})$,

1 - Field measurements, conductance, and $\mathrm{pH}(\mathrm{RU})$,

1 - Resplit for 250-mL RU and 125-mL RC samples, and

2 - Extra samples.

If a larger total-volume sample is required, use 2- or 3-L bottles under the ports of the cone splitter during the first split instead of the 1-L bottles. Additional cone splits may be necessary to achieve the proper volume of subsamples.

Three important issues to remember when using the cone splitter: never overfill a subsample bottle, always pour all of the sample into the splitter, and be careful not to spill any sample water when pouring. 


\section{SEDIMENT SAMPLE}

The sediment sample must be withdrawn from the cone splitter. This subsample should be taken from the first pour through the splitter. However, if for any reason the accuracy of the suspended sediment from a cone-split sample is questioned, a separate sample should be collected directly from the stream using the most appropriate method. The cone-split sediment sample is required, however, even if a separate in-stream sample is collected.

Suspended-sediment data (1) are used in traditional sediment-data interpretation such as computations of loads or erosion rates and (2) provide ancillary information for interpretation of chemistry data, particularly for constituents transported with sediment such as phosphorus. Data for the first purpose may come from the cone splitter or an appropriate sediment-sampling method such as an EWI- or EDIsediment sample. Data for the second purpose must come from a cone-split subsample of the water collected for chemical analyses.

\section{FILTRATION}

\section{INORGANIC CONSTITUENTS}

The preferred procedure for filtering the sample for inorganic-compound analyses is the disposable capsule filter system (see OWQ technical memorandum 94.09, appendix A). This system is required for analyses of samples for trace elements with detection levels of parts per billion (ppb) or less. The capsule filter system allows more colloids to pass through the filter then the conventional membrane filter paper. This system also will help prevent processing contamination and increase the filtration rate and sample volume when high concentrations of suspended sediment are collected. If it is necessary to use the platefilter system, follow the procedures described in OWQ technical memorandum 94.09 (see appendix A).

Filter samples, such as FU, FC, FA, and the sample for alkalinity titration, with a capsule filter system (part OCALA-398 FLD). A peristaltic pump head with Tygon tubing or a Teflon diaphragm pump head with corrugated Teflon tubing should be used to create the pressure required to force these samples through the filter units.

1. Clean all components the sample will contact according to procedures outlined in the "Equipment Cleaning" section of this report.

2. Attach a capsule filter to the tubing and pump $1,000 \mathrm{~mL}$ of DIW through the filter.

3. Remove the tubing from the DIW source and pump until liquid is removed from the capsule filter (facilitated by shaking the filter).

4. Remove the capsule, rinse the outside of the intake tube with sample, and place the tubing in the subsample to be filtered (avoid drawing up settled material). Fill pump and tubing with sample water and then reattach the capsule.

5. Flush the system by filtering about $25 \mathrm{~mL}$ of sample water into the appropriate bottle (fill to the top of the bottom lip of the bottle). Use this filtrate to rinse the bottle and cap.

6. Filter the sample for trace-element analyses or iron and manganese. Fill the bottle to the bottom of the top lip.

7. Filter the remaining samples (mercury, nutrients, major ions, and alkalinity, in that order) by repeating steps 5 and 6 . Always rinse and fill one bottle before proceeding to the next sample. Continue to use a minimal volume for rinsing (approximately $25 \mathrm{~mL}$ ) each bottle and cap

8. Rinse all equipment with DIW immediately after each use and thoroughly clean all equipment as soon as possible before reuse (see section, "Equipment Cleaning"). Properly dispose of the capsule filter system. 


\section{ORGANIC CARBONS}

The organic-carbon samples must be collected separately using a nonstandard, single-vertical, midstream procedure (see section, "Collection Methods") to avoid possible contamination from the methanol cleaning procedure (see section, "Equipment Cleaning"). Processing areas where methanol has been used also should be avoided because even the methanol vapors can cause contamination. Do not use samples split from the churn or cone splitter for organic carbon analysis. The filtration procedures for DOC (LC0113) and SOC (LC0305) analyses use a stainless-steel or Teflon-pressure filter assembly fitted with a $47-\mathrm{mm}$ diameter, silver, $0.45-\mu \mathrm{m}$ pore-size filter and a hand-vacuum pump, peristaltic pump, or a nitrogen air tank that has been fitted with Tygon tubing to filter the sample. The pressure must be regulated to less than $20 \mathrm{lb} / \mathrm{in}^{2}$.

The preservation of samples for DOC and SOC analyses is accomplished by the combined effects of filtration, chilling, and contact with the silver-filter membrane. Silver, which acts as a preservative, is dissolved from the silver filter during filtration. Most organisms will not pass through a $0.45-\mu \mathrm{m}$ filter.

Estimate the suspended-sediment concentration of the stream for filtration volumes, and then proceed to the appropriate section below. A stage/suspended-sediment graph of historical data will aid in estimating the concentrations.

\begin{tabular}{|c|c|c|c|}
\hline \multicolumn{2}{|c|}{$\begin{array}{l}\text { Suspended-sediment } \\
\text { concentration } \\
(\mathrm{mg} / \mathrm{L})\end{array}$} & $\begin{array}{l}\text { SOC sample } \\
\text { volume } \\
(\mathrm{mL})\end{array}$ & $\begin{array}{l}\text { Processing } \\
\text { procedure } \\
\text { (see below) }\end{array}$ \\
\hline 1 & 30 & 250 & $\mathrm{~A}$ \\
\hline 30 & 300 & 100 & B \\
\hline 300 & - $\quad 1,000$ & 30 & C \\
\hline$>$ & - $\quad 1,000$ & 10 & D \\
\hline
\end{tabular}

A. Suspected suspended-sediment concentrations less than $30 \mathrm{mg} / \mathrm{L}$ :

1. Place a silver filter in the filter-unit base between the screen support and the Teflon seal using stainless-steel tweezers.

2. Precondition the silver filter by forcing approximately $25 \mathrm{~mL}$ of organic-free DIW through the filter unit and the silver filter. Discard.

3. Agitate a $250-\mathrm{mL}$ stream sample to resuspend the sediments. Measure $100 \mathrm{~mL}$ into a graduated cylinder and pour into the top of the filter unit.

4. Process the aliquot of sample through the filter into a prebaked, 125-mL amber glass bottle; do not prerinse the bottle. Cap and store at $4^{\circ} \mathrm{C}$ for the DOC analyses.

5. Filter an additional volume of sample through the filter for SOC analyses. Agitate the stream sample, measure the remainder of the volume from the $250-\mathrm{mL}$ sample (approximately $150 \mathrm{~mL}$ ) into the graduated cylinder and dispense into the filter assembly.

6. Force this aliquot of native water through the same filter. Discard.

7. Open the top of filter unit. Rinse any sediments that have adhered to the inside of the unit through the filter with a small amount of organic-free DIW.

8. Reseal unit and force the rinse water through the filter; continue to pressurize until most of the liquid is forced from the filter.

9. Open the bottom of the filter unit and carefully remove the silver filter with stainless-steel tweezers. Fold the filter in half with sediments on the inside (DO NOT wrap filter in aluminum foil) and place in a plastic petri dish for the SOC analyses.

10. Record on the petri dish the volume (approximately $250 \mathrm{~mL}$ ) of sample that passed through the silver filter. Tape the petri dish to prevent it from opening and place in a sealable plastic bag before storing at $4^{\circ} \mathrm{C}$. 
B. Suspected suspended-sediment concentrations, 30 to $300 \mathrm{mg} / \mathrm{L}$ :

1. Place a silver filter in the filter-unit base between the screen support and the Teflon seal using stainless-steel tweezers.

2. Precondition the silver filter by forcing approximately $25 \mathrm{~mL}$ of organic-free DIW through the filter unit and the silver filter. Discard.

3. Agitate a $250-\mathrm{mL}$ stream sample to resuspend the sediments. Measure $100 \mathrm{~mL}$ into a graduated cylinder and pour into the top of the filter unit.

4. Process the aliquot of sample through the filter into a prebaked, 125-mL amber glass bottle; do not prerinse the bottle. Cap and store at $4^{\circ} \mathrm{C}$ for the DOC analyses.

5. Open the top of filter unit. Rinse any sediments that have adhered to the inside of the unit through the filter with a small amount of organic-free DIW.

6. Reseal unit and force the rinse water through the filter. DISCARDING FILTRATE, continue to pressurize until most of the liquid is forced from the filter.

7. Open the bottom of the filter unit and carefully remove the silver filter with stainless-steel tweezers. Fold the filter in half with sediments on the inside (DO NOT wrap filter in aluminum foil) and place in a plastic petri dish for the SOC analyses.

8. Record on the petri dish the $100-\mathrm{mL}$ volume of sample that passed through the silver filter. Tape the petri dish to prevent it from opening and place it in a sealable plastic bag before storing at $4^{\circ} \mathrm{C}$.

C. Suspected suspended-sediment concentrations, 300 to $1,000 \mathrm{mg} / \mathrm{L}$ :

1. Place a silver filter in the filter-unit base between the screen support and the Teflon seal using stainless-steel tweezers.

2. Precondition the silver filter by forcing approximately $25 \mathrm{~mL}$ of organic-free DIW through the filter unit and the silver filter. Discard.

3. Agitate a $250-\mathrm{mL}$ stream sample to resuspend the sediments. Measure $30 \mathrm{~mL}$ into a graduated cylinder and pour into the top of the filter unit.

4. Process the aliquot of sample through the filter into a prebaked, $125-\mathrm{mL}$ amber glass bottle; do not prerinse the bottle. Cap and save this sample; additional filtrate will be added later.

5. Open the top of filter unit. Rinse any sediments that have adhered to the inside of the unit through the filter with a small amount of organic-free DIW.

6. Reseal unit and force the rinse water through the filter. DISCARDING FILTRATE, continue to pressurize until most of the liquid is forced from the filter.

7. Open the bottom of the filter unit and carefully remove the silver filter with stainless-steel tweezers. Fold the filter in half with sediments on the inside (DO NOT wrap filter in aluminum foil) and place in a plastic petri dish for the SOC analyses.

8. Record on the petri dish the (approximately $30 \mathrm{~mL}$ ) volume of sample that passed through the silver filter. Tape the petri dish to prevent it from opening and place it in a sealable plastic bag before storing at $4^{\circ} \mathrm{C}$.

9. Reload the filter unit with another silver filter.

10. Precondition the new filter by forcing approximately $25 \mathrm{~mL}$ of organic-free DIW through the filter unit and silver filter. Discard.

11. Decant from the top of the stream sample (to avoid sediment) an additional $70 \mathrm{~mL}$ into the graduated cylinder and dispense into the filter unit.

12. Force this aliquot of native water through the filter and into the same $125-\mathrm{mL}$ bottle already containing $30 \mathrm{~mL}$ of filtered sample. Discard filter. Cap and store the $100 \mathrm{~mL}$ of filtered sample at $4^{\circ} \mathrm{C}$ for the DOC analyses.

NOTE: As suspended-sediment concentrations increase, the volume of sample that passes through the filter will decrease. It may be necessary to filter a smaller volume at step 11. If this occurs, use a smaller sample aliquot $(20$ or $30 \mathrm{~mL})$ and repeat steps 9 through 12 until a sample of $100 \mathrm{~mL}$ has been filtered for the DOC analyses. 
D. Suspected suspended-sediment concentrations greater than $1,000 \mathrm{mg} / \mathrm{L}$ :

Follow procedure $\mathrm{C}$ when processing samples suspected of having a suspended-sediment concentration greater than $1,000 \mathrm{mg} / \mathrm{L}$, except use a $10-\mathrm{mL}$ sample volume at step 3 for the SOC analyses. Step 11 then will require an additional $90 \mathrm{~mL}$ for the DOC sample.

Clean all equipment immediately after use, wrap with aluminum foil, and store in a sealed container (sealable plastic bag). Avoid working and storing in areas where methanol vapors might contaminate the equipment. The filter assembly and any other equipment (tweezers, graduated cylinder, and so forth) should be routinely cleaned ONLY with organic-free DIW accompanied by an aggressive scrubbing with a nonmetallic brush. DO NOT USE METHANOL OR DETERGENT for routine cleaning.

Regular inspection of the filter assembly is important to determine if additional cleaning is necessary. A dirty filter unit or a suspected contaminated filter unit will require additional cleaning. Scrub filter unit with a solution of 0.1-percent Liquinox and rinse with GALLON ${ }^{\text {r }}$ of tap water (you MUST remove the detergent). Scrub and rinse with organic-free DIW. Remember that three 1-L rinses are more effective than one 3-L rinse. Double wrap the equipment with aluminumi . . il for storage.

\section{ORGANIC COMPOUNDS}

Organic contaminants are manmade, synthetic compounds, many of which control insects (insecticides) and weeds (herbicides). The capillary-column gas chromatography/mass spectrometry (GCMS) method is used for pesticide analyses of organonitrogen herbicides (NWQL schedules 2001 and 2010). Samples collected for chorophenoxy-acid herbicides and carbamates (NWQL schedules 2050 and 2051) use the high-pressure liquid-chromatography (HPLC) method. These synthetic-organic compounds in stream water interact with sediment particles through sorptive processes; therefore, it is important to separate the solid phase from the sample as soon as possible after collection. Depth filters made from glass fibers with a 0.7- $\mu \mathrm{m}$ pore size are used to filter samples for analysis of organic compounds because they can be precleaned with organic solvents or baked at $450^{\circ} \mathrm{C}$. Depth filters have a high-loading capacity, making them more suitable for filtering the larger sample volumes $(1$ to $3 \mathrm{~L}$ ) are needed for organic analysis. More detailed information on filtering samples is found in OWQ technical memorandum 91.09 (see appendix A) or in a report by Sandstrom and others (1992).

The pumping system should be either a valveless metering pump with a ceramic piston (FMIQB-1-CSC) or a Teflon diaphragm head mounted on a 12-volt electric pump drive. The filter support should be made of aluminum, Teflon, or stainless steel with a 142-mm diameter. The filter support is connected to the pump with 1/4-in. convoluted or corrugated Teflon tubing and Teflon or stainless-steel fittings.

All equipment and components should be made of materials that will not contaminate or sorb analytes and are suitable for use with organic solvents such as ceramics, glass, fluorinated polymers (Teflon), stainless steel, or aluminum. The equipment should be precleaned with a Liquinox/tap-water solution (approximately 0.2-percent Liquinox by volume), rinsed with tap water and then with high-purity methanol, and air dried. Do not use the hydrochloric-acid cleaning step for equipment used in this procedure. The following procedures should be done in a clean workplace, free from fumes and dust. The samples processed here should be subsamples directly from the cone splitter.

1. Rinse the filter, tubings, and the filter support by passing AT LEAST $100 \mathrm{~mL}$ of native water through the system; use a precleaned (oven baked at $450^{\circ} \mathrm{C}$ for 2 hours), glass-fiber, $0.7-\mu \mathrm{m}$ pore-size filter (part OCALA-375FLD). Remove the air from the filter support and tubing by opening the vent located on the top of the filter support.

2. Tare weigh a precleaned 1-L amber glass bottle (from NWQL). Filter sample without rinsing the bottle. Collect approximately $1 \mathrm{~L}$ of the filtered sample for each schedule (do not completely fill the bottle; leave about a $2-\mathrm{cm}$ headspace to add conditioner and surrogate).

3. Weigh and record the amount of sample filtered; that is, the total weight minus the tare weight of the bottle.

4. Refrigerate or store filtered sample on ice (approximately $4^{\circ} \mathrm{C}$ ) for additional processing. 


\section{Changing Filiter Paper}

High sediment and colloid concentrations can slow the filtration rate by clogging the filter paper prior to achieving the volume necessary for analyses. Clogging might require changing the filter paper during the filtration procedure. To do this, remove the pump intake line from the stream-water sample bottle and pump dry the filter unit before disassembling. Remove the filtered sample from the filter unit. The unfiltered sample must not come in contact with the bottom half of filter unit while the filter paper is being changed. Fold the clogged filter in half with tweezers, carefully remove, and discard. Rinse the inside of the filter unit with organic-free DIW. Install a new filter paper and condition prior to continuing the filtration process.

\section{Cartridge Processing}

Samples collected for analysis of organic compounds must be processed through a solid-phase extraction (SPE) cartridge within 4 days of collection. Schedules 2001 and 2050 require laboratory-processed SPE, and schedules 2010 and 2051 require field processed SPE. The SPE method utilizes bonded silica, packed into an extraction column, which absorbs specific organic compounds. These compounds subsequently are removed from the extraction column using a solvent. This procedure produces a small sample that is analyzed for selected compounds. This extracted sample can be stored for extended periods before analyses.

1. Record the precleaned SPE cartridge type, lot number, and weight. Condition the SPE cartridge. Use approximately $2 \mathrm{~mL}$ of methanol for schedule 2010 and approximately $2 \mathrm{~mL}$ of ascorbic acid for schedule 2051. Follow with approximately $2 \mathrm{~mL}$ of organic-free DIW to remove excess conditioner. Allow the conditioner and water to flow by gravity through the cartridge. At no time should the cartridge go dry once conditioning has started. If it does, repeat the conditioning process. Maintain the water in the cartridge bed by replacing the water that drains through or by using an on-off valve to prevent the cartridge from draining completely.

2. Add to the filtered sample (from above) approximately $10 \mathrm{~mL}$ of methanol for schedule 2010 or approximately $10 \mathrm{~mL}$ of ascorbic acid for schedule 2051 using a bottle-top dispenser. Weigh and record the sample-plus-methanol weight.

3. Add the surrogate mixture $(1.25 \mathrm{mg} / \mu \mathrm{L})$ contained in the $2-\mathrm{mL}$ amber vial. Use a different surrogate and micropipette for each schedule. Withdraw the solution into the glass bore using a $100-\mu \mathrm{L}$ micropipette and a clean glass bore. Insert the tip into the sample bottle below the surface of the water and press the plunger to deliver the surrogate to the sample. Withdraw the micropipette, remove and discard the glass bore. Rinse the orange-colored Teflon tip with solvent. Cap and swirl the sample to mix.

4. Process the filtered sample through the SPE cartridge with a valveless, piston-type metering pump (FMI-RHB-0-CKC) fitted with 1/8-in. Teflon tubing. Insert the tubing from the inlet side of the pump into the sample bottle. Turn on the pump, allow the air to be rinsed from the tubing, then attach the outflow pump line to the SPE cartridge with a Luer-Lok fitting. For schedule 2010, use a female Luer-Lok fitting attached to the small end of the cartridge and invert the cartridge to discard any conditioning water remaining in the SPE reservoir. For schedule 2051, use a male Luer-Lok fitting and cartridge adapter attached to the large barrel end of the cartridge. Pump the sample through the cartridge at 20 to $25 \mathrm{~mL} / \mathrm{min}$. Collect the extracted water that passes through the cartridge in a plastic 1-L beaker. After the sample has been pumped through the cartridge, turn off the pump, and disconnect the SPE cartridge.

5. Remove excess water from the SPE cartridge using a syringe to blow out the water. Record the final weight of the sample. Write the sample identification number on the side of the cartridge and store in a $40-\mathrm{mL}$ amber glass ampule. Store cartridges in a cool place (approximately $4^{\circ} \mathrm{C}$ ).

Clean all equipment after use by rinsing with a phosphorus-free detergent ( 0.2 percent) and then several rinses with tap or distilled water to remove the detergent and approximately $30 \mathrm{~mL}$ of methanol. Wrap all openings with Teflon tape or aluminum foil. 


\section{PRESERVATION}

Many of the ions normally present in natural waters change due to chemical and physical reactions, such as oxidation, reduction, precipitation, adsorption, and ion exchange, before analyses in a laboratory. Therefore, samples for many constituents must be stabilized by preservation. Some examples of preservative treatment are refrigeration to minimize chemical change caused by biologic activity and the addition of acid to prevent the precipitation of cations.

Below are some examples of bottles, caps, and treatments for various analyses.

\begin{tabular}{llll}
\hline Analyses & Bottle type & Bottle cap & Treatment \\
\hline Anions & Clear plastic & Black & FU \\
Cations & Clear plastic & Clear & FA \\
Nutrients & Brown plastic & Black & RC,FC \\
Trace elements & Clear plastic & Clear & FA \\
Organic compounds & Brown glass & Teflon lined & FC \\
\hline
\end{tabular}

$\mathrm{F}=$ filtered

$\mathrm{U}=$ untreated

$\mathrm{A}=$ nitric acid $\left(\mathrm{HNO}_{3}\right)$

$\mathrm{R}=$ raw (unfiltered)

$\mathrm{C}=$ chill and maintain to $4^{\circ} \mathrm{C}$

Preservatives, such as nitric acid $\left(\mathrm{HNO}_{3}\right)$, sulfuric acid $\left(\mathrm{H}_{2} \mathrm{SO}_{4}\right)$, hydrochloric acid $(\mathrm{HCl})$, nitric acid/potassium dichromate $\left(\mathrm{HNO}_{3} / \mathrm{K}_{2} \mathrm{Cr}_{2} \mathrm{O}_{7}\right)$, sodium hydroxide $(\mathrm{NaOH})$, and phosphoric acid $\left(\mathrm{H}_{3} \mathrm{PO}_{4}\right)$, are available in ampules from OCALA supply. Every measure should be taken to reduce the possibility of contaminating samples and equipment during the preservation process. A preservation chamber will assist in this effort. Be sure the outside of the preservative ampules are clean. Bottles that require no preservation should be set aside in the shipping container. Do not add mercuric chloride $\left(\mathrm{HgCl}_{2}\right)$ to the samples that will be analyzed for nutrients (RC and FC). Samples collected for nutrient analyses should be chilled only (see OWQ technical memorandum 94.16, appendix A). The order in which the preservatives are added also should be considered. ALWAYS WEAR PERSONAL-PROTECTIVE EQUIPMENT (GOGGLES, GLOVES, AND APRON).

1. Preserve samples that require acids (nitric, sulfuric, hydrochloric, and phosphoric) inside a preservation chamber,.

2. Use the same chamber to add nitric-acid/potassium-dichromate solution to the samples that will be analyzed for total and dissolved mercury (RAM and FAM). Discard the gloves worn during these procedures along with the ampules. Wash hands thoroughly.

3. Change processing chambers and complete any other preservation techniques, such as the addition of sodium hydroxide, zinc acetate, or copper sulfate. If any of these bottles or remaining bottles require chilling, place them on ice. Discard the gloves worn during these procedures along with the acid ampules. Wash hands thoroughly.

By following this sequence for sample preservation, the risk of contaminating a sample with the residue of a preservative left in the air or on the gloves is reduced. Clearly, great care must be exercised in the field to prevent cross contamination. Acid and potassium-dichromate ampules should be stored and transported separately. Dispose of used ampules properly. If there are any questions concerning the correct preservation technique or the proper disposal of used ampules, consult your District Water-Quality Specialist or refer to OWQ technical memorandums $90.01,92.11,94.09$, and 94.16 (see appendix A). 


\section{DISTRIBUTION}

All bottles must be clearly labeled with a waterproof marker or preprinted labels so the NWQL can sort the bottles for the appropriate analyses. The minimum information required is the site identification number, date and time, sample designation (bottle type), and schedule number or lab code as shown below:

$$
\begin{gathered}
09498500 \\
\text { 01-31-1993 @ } 1200 \\
\text { RA } \\
\text { SCH-2001 (or LC00114) }
\end{gathered}
$$

A NWQL analytical services request form needs to be included with each sample. The forms and the instructions for completing the form are available from the NWQL. Be sure to retain the carbon copy of the form.

Place all glass containers in padded sleeves or pack in some other suitable manner to prevent breakage during shipment. Chilled samples need an adequate amount of ice. Good results have been obtained by packing the chilled bottles in a volume of ice equal to approximately twice the volume of the chilled sample. The amount of ice necessary varies depending on the length of time in transit from field to laboratory and the time of year. Insulated water coolers from 1 to 5 gal in volume make good shipping containers if the integrity of the container is ensured by removing the spigot assembly and sealing with a silicon or epoxy sealer. Larger volumes of chilled samples can be sent in ice chests as long as maximum weight restrictions of the carrier are not exceeded. Guidelines on shipping samples are discussed in OWQ technical memorandum 92.06 (see appendix A).

Samples should be sent to the NWQL on the day collected when possible. The NWQL also prefers to have all bottles for a single sample sent in one container. However, nutrient samples must be sent in a separate container. Unchilled samples can be sent separately from the chilled samples.

The NWQL has issued the following guidelines:

1. Inspect and replace any broken or leaking coolers. Spouts must be sealed. As part of a program to enhance relations with the post office, the laboratory will not return damaged and leaking coolers.

2. Line each shipping container with a plastic bag.

3. Make sure all bottle caps are screwed on tightly.

4. Place all 1-L glass containers in individual foam sleeves or in a foam box designed for shipping to prevent breakage when samples are sent in coolers.

5. Ice should be placed inside a double plastic bag in the shipping container.

6. During the summer, in particular, the cooler and samples should be prechilled. Pack the samples with fresh ice, at least a volume of ice equal to the volume occupied by the samples, but preferably twice the volume of ice to samples.

7. Protect the log-in forms and return labels from the ice by placing them in a plastic bag; the plastic bag should be sealed and fastened to the lid of the cooler with tape.

8. The plastic liner bag must be carefully sealed with a wire tie and the shipping container taped shut. 


\section{FIELD ANALYSES}

Measurements of specific conductance, water temperature, dissolved oxygen, $\mathrm{pH}$, and alkalinity could change dramatically within a few minutes or hours after sample collection. Immediate analysis in the field is required if results representative of in-stream conditions are to be obtained.

Water temperature and dissolved oxygen should be measured directly from the stream, and several readings are required in the cross section to obtain a stream average. Specific conductance, $\mathrm{pH}$, and alkalinity should be measured from a cone-split subsample so that these results will be from the same water matrix as the other chemical analyses. A single field meter that measures specific conductance, water temperature, $\mathrm{pH}$, and dissolved oxygen directly in the stream may be used if stream profiles are performed regularly. These profiles must confirm that the direct in-stream measurements are comparable to the values from a cone-split sample.

Field water-quality instruments, support equipment, and the reagents used for analyses are listed in table 3, in reports by Fishman and Friedman (1985) Ward and Hair (1990), and in selected OWQ technical memorandums $(79.10,81.08,81.17,82.05$, and 89.01, see appendix A).

Maintain an instrument $\log$ and review it prior to each field trip. The operation and calibration of all field instruments (including back-up meters and electrodes) should be checked to ensure that all are in good working condition.

\section{TEMPERATURE}

The stream water temperature can affect density and gas solubility, and density affects the mixing of different water masses, especially seasonal stratification. Temperature also affects the rate of chemical reactions, biological activity, conductivity, dissolved oxygen, and $\mathrm{pH}$.

Because of possible environmental contamination if broken, mercury-filled thermometers are not acceptable for field use (see OWQ technical memorandum 94.02, appendix A). The recommended procedure for determining field temperatures is a thermistor, an electrical device made of a solid semiconductor with a high temperature coefficient of resistivity. Thermistors can be constructed with a high sensitivity, but are subject to a variety of errors. Therefore, the calibration should be checked in the laboratory at several temperatures using an American Society for Testing and Materials (ASTM) thermometer to ensure the required accuracy. Never carry a mercury-filled ASTM thermometer in the field.

Field measurements of temperature should include both air-temperature and water-temperature readings. Air-temperature readings should be made by placing a dry thermistor in a shaded area protected from strong winds, but open to adequate air circulation. Avoid areas that may have radiant heat such as near metal walls or sides of vehicles. Allow the thermistor to equilibrate 3 to 5 minutes before recording the temperature.

Water temperatures should represent the mean temperature of the stream at the time of observation. A horizontal and vertical cross-section profile will determine the variability, if any, that exists. Streams with highly variable temperature profiles should have several readings averaged to use as the mean and those variations should be documented. Streams with a fairly uniform temperature (less than $2^{\circ} \mathrm{C}$ variance 95 percent of the time) generally will have one measurement that can be made and reported as the stream temperature. Make this measurement by suspending (from a weighted line) or placing a thermistor in midstream. Shade the thermistor probe to prevent erroneous readings caused by direct solar radiation. The thermistor should be immersed in the stream for a minimum of 1 minute prior to making measurements. Report all routine temperature measurements to the nearest $0.5^{\circ} \mathrm{C}$. For special studies where more precision is required, verify the accuracy and report temperatures to the requested precision. 


\section{SPECIFIC CONDUCTANCE}

Conductance is the reciprocal of resistance in ohms and is a measure of the capacity of water or other substance to conduct an electrical current. Specific conductance is the conductance measured at $25^{\circ} \mathrm{C}$ and is reported in microsiemens per centimeter at $25^{\circ} \mathrm{C}$. The specific conductance of water is determined by the types and quantities of dissolved substances in the water. Thus, specific conductance indicates the concentration of dissolved solids in water.

The specific conductance of water may change significantly with time because of pollution, precipitation, adsorption, ion exchange, oxidation, and reduction. Therefore, specific conductance should be measured in the field with an accurate conductivity meter. Many commercial conductivity meters are available on the market. All meters come with operating instructions, and users should be totally familiar with these instructions. The following are some important features and characteristics of a specific-conductance meter:

1. Automatic temperature compensating (direct specific-conductance reading).

2. Multiple measurement ranges from 0 to $200,000 \mu \mathrm{S} / \mathrm{cm}$ at $25^{\circ} \mathrm{C}$ with 1-percent accuracy and three-number digital readout.

3. Platinum, carbon, stainless-steel, or gold electrode.

4. Dip-type electrode.

Conductivity electrodes must be clean to produce accurate results. Because of the wide variety of electrode material, the instructions provided by the manufacturer should be followed. Rinse the electrode thoroughly with DIW after cleaning.

\section{CALIBRATION}

Specific-conductance standards, 10 to $50,000 \mu \mathrm{S} / \mathrm{cm}$ at $25^{\circ} \mathrm{C}$, are available from OCALA supply for meter calibration. Prior to every water-quality field trip and again onsite, standards should be used to calibrate the meter and to check meter calibration. Document calibration checks in the instrument log. Used standards should not be returned to the stock container.

Calibration and operating procedures vary with meter types and manufacturers. The procedures described below are generalized steps that should be followed and will apply to most meters used for field measurements:

1. Presoak electrode in DIW at least overnight.

2. Choose two specific-conductance standards that will bracket the expected value of the sample to be measured.

3. The standards should be approximately the same temperature as the sample to be measured.

4. Use the calibration standard closest to the expected value of the sample to be measured. Rinse the container and electrode with standard. Pour calibration standard into container holding the electrode. Allow a minute or two for equilibration and then discard the standard.

5. Calibration setting: Pour fresh calibration standard into the container holding the electrode. The electrode should not touch the sides or bottom of the container. Note the meter reading and ADJUST meter to the known standard value.

6. Discard calibration standard into a waste container.

7. Rinse electrode and container with the second standard. The second standard will bracket the range of expected stream conductance. Pour check standard into rinsed container holding the electrode. Allow to equilibrate, and then discard check standard into a waste container.

8. Calibration check: Pour second standard into the rinsed container holding the electrode. This check reading should be within 5 percent of the known standard value. If not, repeat entire calibration procedures. Electrode cleaning or replacement, a different meter, or both might be needed.

NOTE: Switching meter calibration range will require recalibrating.

9. Discard check standard into a waste container and then rinse electrode and container with DIW.

10. Record all calibration information in the instrument $\log$ and on the field notes. 
Measurements of specific conductance at stream sites should be made from an unfiltered subsample from the cone splitter. If a direct in-stream measurement is made, several readings are necessary (vertically and horizontally) in the cross section to determine a mean value.

1. Rinse electrode and container with sample water. Pour sample water into container holding the electrode. Allow to equilibrate for a minute and then discard the rinse sample into a waste container.

2. Sample measurement: Pour fresh sample into the rinsed container holding the electrode. Record the specific-conductance value on the field notes.

3. Discard sample into a waste container and then rinse electrode and container with DIW. It is advisable to store electrode in DIW.

4. Conductivity measurements are reported as specific conductance and are expressed as microsiemens per centimeter at $25^{\circ} \mathrm{C}$. Results are reported to three significant figures, whole numbers only.

pH

The $\mathrm{pH}$ of a solution is a measure of the effective hydrogen-ion concentration (activity). In aqueous solutions, $\mathrm{pH}$ is controlled primarily by the hydrolysis of salts of strong bases and weak acids or vice versa. The $\mathrm{pH}$ is expressed in logarithmic units using a scale from 0 to 14 . Solutions having a $\mathrm{pH}$ of less than 7 are described as acid; solutions with a $\mathrm{pH}$ of more than 7 are described as basic or alkaline. Dissolved gases, such as carbon dioxide, hydrogen sulfide, and ammonia, appreciably affect $\mathrm{pH}$. Degasification (for example, loss of carbon dioxide), precipitation [for example, calcium carbonate $\left(\mathrm{CaCO}_{3}\right)$ ], and other chemical, physical, and biological reactions may cause the $\mathrm{pH}$ of a water sample to change significantly within several hours or even minutes after sample collection. Immediate analysis of a $\mathrm{pH}$ in the field is REQUIRED if dependable results are to be obtained. A thorough discussion of $\mathrm{pH}$ is presented in a report by Wood (1981), and low ionic-strength water (less than $50 \mu \mathrm{S} / \mathrm{cm}$ conductance) is discussed in a report by Busenberg and Plummer (1987). Some important features of the meters and electrodes include the following:

1. Digital (LCD) meter readout with $0.02 \mathrm{pH}$ unit accuracy.

2. Slope correction (preferably with percent of slope readout).

3. Standard BNC electrode connector.

4. Plastic or glass, liquid-filled, combination $\mathrm{Ag} / \mathrm{Cl}$ electrode.

Because a large variety of $\mathrm{pH}$ meters and electrodes are available on the market, it is extremely important that operators are thoroughly familiar with the instruction manual provided by the manufacturer.

Electrodes must be clean and properly operating to produce accurate results. The liquid junction also must be free flowing, and the electrolyte solution in the electrode must be at the proper level. Because of the variety of electrodes available, follow the cleaning and storing instructions provided by the manufacturer. Never wipe the $\mathrm{pH}$ electrode membrane with anything or store it dry (check manufacturer's instructions). 


\section{CALIBRATION}

Buffers used to calibrate and check pH meters are available from OCALA supply. The standard buffers have values of $\mathrm{pH} 4,7$, and 10 with a relatively high ionic strength. Two $\mathrm{pH}$ buffers are needed to calibrate the pH meter (4 and 7 or 7 and 10). Document calibration checks in the instrument log. Used standards should not be returned to the stock container.

Because calibration and operating procedures vary with meter types and manufacturers, the procedures described below are generalized steps that will apply to most meters used for field measurements:

1. Remove filling plug on refillable electrodes prior to use. Use only the solution recommended by the electrode manufacturer when filling solution must be added. The liquid-filled $\mathrm{pH}$ electrodes should always be stored upright.

2. Bring $\mathrm{pH}$ buffers to the temperature of the sample to be measured (within a few degrees). Apply temperature-correction factors when calibrating the $\mathrm{pH}$ meter.

3. Rinse electrode, thermistor, a small Teflon-coated magnetic stirring bar, and a glass beaker with pH-7 buffer. Pour buffer into rinsed container holding electrode, thermistor, and stirring bar. Allow temperature to equilibrate for a minute and then discard buffer into a waste container.

4. Calibration: Pour fresh pH-7 buffer in the same beaker holding the equipment. The $\mathrm{pH}$ electrode must not be resting on the bottom or touching the sides of the container. Place the beaker on a magnetic stirrer. Measure temperature, remove thermistor, and adjust meter to the temperature of the buffer. With the stirrer on low (do not create a vortex), adjust meter reading to the known buffer value at the specific temperature. Discard $\mathrm{pH}$ buffer into a waste container.

NOTE: Turn pH meter to "standby" (or "off" on meters without standby) position prior to removing electrode from a solution.

5. Select a second buffer to bracket the expected stream $\mathrm{pH}$. Use a $\mathrm{pH}-10$ buffer when expected $\mathrm{pH}$ is greater than 7 and a $\mathrm{pH}-4$ buffer when the expected $\mathrm{pH}$ is less than 7 . Always use a $\mathrm{pH}-4$ buffer as the second buffer when titrating for alkalinity. Rinse electrode, thermistor, and stirring bar with DIW. Rinse another clean beaker, electrode, thermistor, and stirring bar with the second buffer ( $\mathrm{pH} 4$ or 10). Pour second buffer into that container. Allow temperature to equilibrate for a minute and then discard buffer into a waste container.

6. Slope adjustment: Pour fresh $\mathrm{pH}$ buffer in the same beaker holding the equipment. Measure temperature and remove thermistor. Set meter temperature to the buffer temperature and, with the stirrer on low, adjust slope to the value of $\mathrm{pH}$ buffer. (Some meters have separate slope-adjustment knobs, whereas others use the temperature knob. Always refer to instruction manual when uncertain.) Discard $\mathrm{pH}$ buffer into a waste container.

7. Rinse electrode, thermistor, and stirring bar with DIW. Repeat steps 3 and 4 to ensure that any slope adjustments did not change the calibration adjustment. This is a check so adjustment should not be needed. If adjustment is required, repeat the entire calibration procedure.

8. Record all calibration information in the instrument $\log$ and on the field notes.

\section{MEASUREMENT}

Measurements of $\mathrm{pH}$ at stream sites should be made from a raw (unfiltered) subsample from the cone splitter. If a direct in-stream measurement is made, several readings are necessary (vertically and horizontally) in the cross section to determine a mean value.

1. Rinse electrode, thermistor, stirring bar, and container with stream water. Pour stream water into container holding the electrode, thermistor, and stirring bar. Allow the temperature to equilibrate and the electrode to precondition itself to the sample. Discard sample in waste container.

2. Measurement: Pour fresh sample into the same container holding the equipment. Measure and set temperature and remove thermistor. Measure $\mathrm{pH}$ and record on field notes. Discard sample in waste container.

3. Rinse electrode, thermistor, and stirring bar with DIW, and store electrode as recommended by the manufacturer.

4. Measurements of $\mathrm{pH}$ are reported in $\mathrm{pH}$ units. Results are reported to the nearest $0.1 \mathrm{pH}$ unit. 


\section{ALKALINITY, BICARBONATE, AND CARBONATE}

Alkalinity refers to the capacity of water to neutralize an acid by means of chemical buffering. In most waters, alkalinity is caused primarily by the presence of bicarbonate $\left(\mathrm{HCO}_{3}^{-1}\right)$ and carbonate $\left(\mathrm{CO}_{3}^{-2}\right)$ ions. Some noncarbonate contributors to alkalinity include hydroxide, silicate, borate, and organic ligands, especially acetate and propionate (Hem, 1985). Because bicarbonate and carbonate predominate in most waters, their determination is essential in studies involving carbonate-chemistry and equilibrium calculations. Alkalinity is commonly used in the determination of the cation/anion balance of a water sample.

Degasification, precipitation, and other chemical and physical reactions can cause the concentrations of bicarbonate and carbonate to change significantly within several hours or even minutes after sample collection. Consequently, field determinations of alkalinity, bicarbonate, and carbonate are needed in addition to laboratory determinations. Determine alkalinity, bicarbonate, and carbonate concentrations on a FILTERED sample. The section on filtration describes the proper method.

Several methods can be used to determine total alkalinity, bicarbonate, and carbonate. All of the methods involve titrating a water sample with a standard solution of sulfuric acid and monitoring the change in $\mathrm{pH}$ as the acid is added to the sample. The presence and quantity of hydroxide (if sample $\mathrm{pH}$ is 10.4 or greater), carbonate (sample $\mathrm{pH}$ is approximately 8.3 or greater), and bicarbonate (sample $\mathrm{pH}$ approximately 4.5 or greater) is determined by the $\mathrm{pH}$ of the sample and the quantity of acid added. The two methods commonly used are the fixed end-point and incremental methods. Additional information on alkalinity, bicarbonate, and carbonate determinations is presented in OWQ technical memorandum 82.05 (see appendix A) and in reports by Wood (1981) and Fishman and Friedman (1985).

\section{FIXED END-POINT METHOD}

The fixed end-point method determines bicarbonate and carbonate by preselecting end points that correspond to true equivalence points under ideal conditions. Using sulfuric acid for titration, the sample $\mathrm{pH}$ is lowered to 8.3 for carbonate and $\mathbf{4 . 5}$ for bicarbonate. This method is not preferred because it is less accurate than the incremental method. Instructions on the fixed end-point method are given in a report by Sylvester and others (1990) (see appendix B).

\section{INCREMENTAL METHOD}

The incremental method, which determines alkalinity, bicarbonate, and carbonate values more accurately than the fixed end-point method, is preferred by the USGS and should be used for NAWQA. Rather than assuming the equivalence points to be at $\mathrm{pH} 8.3$ and 4.5, the incremental method determines the actual equivalence points by constructing a titration curve (plotting $\mathrm{pH}$ and the volume of sulfuric acid) and selecting the inflection point of the curve as the end point. The end point also can be determined by plotting the change in $\mathrm{pH}$ divided by the change in volume of sulfuric acid added, noting the maximum rate of change of $\mathrm{pH}$ per volume of acid added. The dilute-acid titrant (available from OCALA supply) should be added using a digital titrator. The digital titrator can dispense small quantities of acid and is preferred because the Quality Water Service Unit (OCALA) performs quality-controls on the normality of the titrant used in the digital titrator.

\begin{tabular}{ccc}
\hline $\begin{array}{c}\text { Expected } \\
\text { alkalinity } \\
(\mathrm{mg} / \mathrm{L})\end{array}$ & $\begin{array}{c}\text { Sample } \\
\text { volume } \\
(\mathrm{mL})\end{array}$ & $\begin{array}{c}\text { Acid } \\
\text { strength } \\
(\mathrm{N})\end{array}$ \\
\hline$<20$ & 100 & 0.160 \\
$20-50$ & 50 & 0.160 \\
$50-150$ & 100 & 1.600 \\
$>150$ & 50 & 1.600 \\
\hline
\end{tabular}


1. Calibrate $\mathrm{pH}$ meter (see section on $\mathrm{pH}$ ).

2. Depending upon the expected alkalinity, select the sample volume and the appropriate strength titrant cartridge, 0.160 normal $(\mathrm{N})$ or $1.600 \mathrm{~N}$ sulfuric acid.

3. Assemble the digital titrator by placing the titrant cartridge into the titrator and inserting a clear delivery tube into the cartridge. Turn delivery knob to release a few drops of titrant (into a waste container) from the end of the delivery tube, gently blot any droplets adhering to the end of the tube, and set digital counter to a ZERO reading. Inspect the delivery tube; if air bubbles are present, continue to turn knob, expelling the acid until bubbles are removed. Always make sure the delivery tube is below the water surface when dispensing acid into the sample.

4. With a volumetric pipet put selected volume of FILTERED sample (50 or $100 \mathrm{~mL}$ ) into a clean beaker containing a thermistor and a small Teflon-coated, magnetic stirring bar. Record volume of sample that will be titrated on the field notes.

5. Place $\mathrm{pH}$ electrode (previously rinsed with DIW) into sample to be titrated and place beaker on a magnetic stirrer.

6. Measure temperature, remove thermistor, and set meter temperature to sample temperature.

7. Turn on stirrer and adjust stirring rate to low (do not create a vortex). Turn on pH meter, allow reading to stabilize, and then read and record initial $\mathrm{pH}$ value.

NOTE: IF SAMPLE pH IS LESS THAN 8.3, OMIT STEP 8.

8. If sample $\mathrm{pH}$ is greater than 8.3 , add sulfuric acid by small increments ( 1 to 3 digital counts at a time) until the $\mathrm{pH}$ of the sample is below 8.0. Record $\mathrm{pH}$ and digital-counter reading after each addition of acid. Allow 15 to 20 seconds for equilibration between incremental additions. Sample should be gently stirred with a magnetic stirrer or appropriate stirring device.

9. Titrate RAPIDLY to approximately $\mathrm{pH} 5.5$. Allow 15 to 20 seconds for equilibration and record the digital-counter reading.

10. Add acid by small increments ( 1 to 3 digital units at a time) from $\mathrm{pH} 5.5$ to 4.0. Allow 15 to 20 seconds for equilibration between incremental additions of acid and record $\mathrm{pH}$ and digital-counter readings.

11. Construct a titration curve plotting the digital counts of titrant (sulfuric acid) as a function of $\mathrm{pH}$. The end points are the inflection points of the curve (near 8.3 or 4.5 ), the points at which the $\mathrm{pH}$ changes are greatest for volume of acid added. An alternate method is to plot the rate of change of $\mathrm{pH}$ with the change in digital counts to determine the inflection points as follows:

$$
\frac{\Omega p H}{\Omega \text { digital count. }}
$$

12. Use the digital count at the maximum rate of $\mathrm{pH}$ change that represents the appropriate end points to determine the following:

For $1.600 \mathrm{~N}$ acid titration

$$
\begin{array}{ll}
\text { Carbonate }\left(\mathrm{mg} / \mathrm{L} \text { as } \mathrm{CO}_{3}{ }^{-2}\right) & =2.40 \times \mathrm{DCA}[50-\mathrm{mL} \text { sample] } \\
& =1.20 \times \mathrm{DCA}[100-\mathrm{mL} \text { sample] } \\
\text { Bicarbonate }\left(\mathrm{mg} / \mathrm{L} \text { as } \mathrm{HCO}_{3}^{-1}\right) & =2.44 \times(\mathrm{DCB}-2 \times \mathrm{DCA})[50-\mathrm{mL} \text { sample] } \\
& =1.22 \times(\mathrm{DCB}-2 \times \mathrm{DCA})[100-\mathrm{mL} \text { sample] }
\end{array}
$$

For $0.160 \mathrm{~N}$ acid titration

$$
\begin{array}{ll}
\text { Carbonate }\left(\mathrm{mg} / \mathrm{L} \text { as } \mathrm{CO}_{3}^{-2}\right) & =0.240 \times \mathrm{DCA}[50-\mathrm{mL} \text { sample] } \\
& =0.120 \times \mathrm{DCA}[100-\mathrm{mL} \text { sample] } \\
\text { Bicarbonate }\left(\mathrm{mg} / \mathrm{L} \text { as } \mathrm{HCO}_{3}^{-1}\right) & =0.244 \times(\mathrm{DCB}-2 \times \mathrm{DCA})[50-\mathrm{mL} \text { sample] } \\
& =0.122 \times(\mathrm{DCB}-2 \times \mathrm{DCA})[100-\mathrm{mL} \text { sample] }
\end{array}
$$

where

DCA is digital count near end point $8.3 \mathrm{pH}$ and

DCB is digital count near end point $4.5 \mathrm{pH}$.

Alkalinity $\left(\mathrm{mg} / \mathrm{L}\right.$ as $\left.\mathrm{CaCO}_{3}\right)=\left[\left(\mathrm{CO}_{3}^{-2} / 30\right)+\left(\mathrm{HCO}_{3}^{-1} / 61\right)\right] \times 50$

13. Report concentrations of alkalinity as equivalent calcium carbonate as $\mathrm{CaCO}_{3}$, in milligrams per liter, bicarbonate as $\mathrm{HCO}_{3}^{-1}$, in milligrams per liter, and carbonate as $\mathrm{CO}_{3}^{-{ }^{3}}$, in milligrams per liter, as follows: less than $1,000 \mathrm{mg} / \mathrm{L}$, whole numbers; $1,000 \mathrm{mg} / \mathrm{L}$ and above, three significant figures. 


\section{DISSOLVED OXYGEN}

Oxygen dissolved in stream water is derived from the air and from the oxygen given off by aquatic plants in the process of photosynthesis. The solubility of oxygen in water is dependent upon the partial pressure of oxygen in the air, the temperature of the water, and the mineral content of the water.

The field method most commonly used for measuring dissolved oxygen in water is the cathode/electrometric method, which uses a membrane-type electrode. Oxygen passes through a membrane at a rate relative to the partial pressure of oxygen outside the membrane. When oxygen diffuses through the membrane, it is rapidly consumed at the gold cathode. The consumption of oxygen causes a current to flow through the cell. The current is directly proportional to the quantity of oxygen consumed and can be converted to concentration units. The membrane is permeable to gases other than oxygen; therefore, halogens, hydrogen sulfide, sulfur dioxide, and helium will interfere with the ability of the probe to give correct readings. Several new methods for determining in-stream dissolved oxygen are equally dependable. Follow the instructions provided by the manufacturer for calibration and measurements when using other methods for determining dissolved oxygen. A more thorough discussion on the principles of the electrometric method of measuring dissolved oxygen is in a report by Wood (1981) and in OWQ technical memorandum 79.10 (see appendix A).

\section{PROBE MAINTENANCE}

Field probes commonly used are the Yellow Springs Instrument (YSI) series 5700 probes. Probe membranes should be checked for wrinkles and entrapped air bubbles. If present, replace membrane and electrolyte. Check for leakage of electrolyte around the membrane and the pressure-compensation diaphragm. The gold cathode should be glossy. Membranes will not last indefinitely; if the electrolyte evaporates and bubbles form under the membrane or the membrane becomes damaged or overgrown with biological growth, replace the membrane after flushing the reservoir with potassium-chloride (KC1) electrolyte. The membrane and electrolyte also should be replaced if meter readings become erratic or calibration is unstable. The zero reading on the meter should be rechecked after each membrane change. The method of probe preparation is as follows:

1. Prepare the electrolyte by dissolving the potassium chloride crystals with DIW.

2. Remove the guard around the sensor and then remove the O-ring and membrane.

3. The gold cathode at the probe tip should always be bright and untarnished. Wipe the cathode with a clean, lint-free cloth or a pencil eraser to clean. Never use abrasives or chemicals.

4. Thoroughly rinse the sensor tip with potassium chloride solution.

5. Invert the probe and fill with potassium chloride electrolyte. Pump the diaphragm near the middle of the probe with a pencil eraser or blunt tool to remove the air bubbles. Continue filling and pumping until no more air bubbles appear. Some probes have no diaphragm and can be filled simply by adding potassium chloride solution until no air bubbles appear.

6. Remove a membrane from the kit and secure it between the thumb and side of probe near the probe tip. Add as much electrolyte as possible to the probe tip. Handle membrane only at the edges to keep it clean and dust free.

7. Grasp the free end of the membrane with the thumb and forefinger. With one continuous motion, stretch the membrane up and over the probe tip and down the other side.

8. Roll the O-ring over the end of the probe. There should be no wrinkles in the membrane or air bubbles trapped under the membrane. Wrinkles can be removed by tugging lightly on the edges of the membrane. Repeat steps 2 through 8 if wrinkles, air bubbles, or pin holes are evident.

9. Trim off excess membrane and replace the sensor guard. 


\section{CALIBRATION}

Keep a $\log$ of calibration information for each meter and probe. A number of general precautions and procedures should be followed prior to and during calibration of the dissolved-oxygen meter.

1. Recharge dissolved-oxygen meter overnight prior to any measurement.

2. Attach the dissolved-oxygen probe and turn instrument function switch to any operational position (for example, REDLINE) 1 hour before use to ensure stability of operation. Leave meter on until final measurement for the day is completed.

3. Check REDLINE and ZERO and adjust as needed. Recharge or replace batteries if meter will not adjust to REDLINE.

4. Ambient-atmospheric pressure is needed for meter calibration and determining dissolved-oxygen percent saturation of the water being measured. Ambient-atmospheric pressure is true atmospheric pressure at station (NOT adjusted to sea level). Use a barometer to measure ambient-atmospheric pressure onsite. The calibration of all field barometers should be checked before each field trip.

\section{Barometer Callbration}

Calibrate the barometer with information from the nearest weather station or airport. The barometric-pressure readings reported by a weather station are adjusted to sea level, however, and must be converted to the elevation of the field site to enable comparison among location readings. Use the following chart to determine the values to subtract from barometric readings reported at sea level.

$\begin{array}{cc}\begin{array}{c}\text { Elevation } \\ \text { (feet) }\end{array} & \begin{array}{c}\text { Subtract } \\ \text { (millimeter mercury) }\end{array} \\ 1,000 & 27 \\ 2,000 & 53 \\ 3,000 & 79 \\ 4,000 & 104 \\ 5,000 & 128 \\ 6,000 & 151\end{array}$

\section{Alr-Calibration Chamber in Water}

The air-calibration chamber is the preferred procedure because it permits calibration of the oxygen meter at the temperature of the water in which the dissolved-oxygen content will be measured, thereby minimizing errors caused by temperature differences. The calibration chamber also is designed to allow the membrane surface of the probe to be at ambient-atmospheric pressure while in the chamber. 
1. Place probe and calibration chamber in stream water ( 3 to 5 minutes) until they equilibrate with the stream temperature.

2. Remove probe and chamber from stream and pour excess water from chamber. Insert dissolved-oxygen probe into the wet chamber. The air inside the chamber should be saturated with water vapor.

CAUTION: Be sure that no water can leak into the calibration chamber and no moisture remains on the membrane; this could reduce the rate of oxygen diffusion through the membrane, thereby producing erroneous results.

3. Place calibration chamber in the water where the dissolved-oxygen content will be measured. Allow 3 to 5 minutes for the temperature of the air inside the chamber to equilibrate with the water.

4. Read the ambient atmospheric pressure from the barometer to the nearest $5 \mathrm{~mm}$ of mercury. Recheck the REDLINE and ZERO reading on the oxygen meter and adjust if necessary.

5. Measure temperature in the calibration chamber to the nearest $1.0^{\circ} \mathrm{C}$ using the thermistor in the dissolved oxygen probe.

6. Use table 4 to determine the dissolved-oxygen saturation value at the measured water temperature and true atmospheric pressure. Interpolate between readings for an accurate correction.

7. Select the scale $(0-10 \mathrm{mg} / \mathrm{L}$ or $1-20 \mathrm{mg} / \mathrm{L})$ for the dissolved-oxygen measurement and adjust CALIBRATION control until meter reads the dissolved-oxygen saturation value determined from the oxygen-solubility tables. Recalibrate if the scale is changed.

8. After calibration, check the dissolved-oxygen meter and probe in a dissolved-oxygen free solution. This can be accomplished by inserting the probe into a sodium-sulfate/cobalt-chloride solution and measuring the dissolved oxygen. If the instrument reading exceeds $0.2 \mathrm{mg} / \mathrm{L}$, the membrane and electrolyte or the entire probe might need to be replaced. Thoroughly rinse probe with DIW to remove any residue of the zero-dissolved-oxygen solution.

Meter is now calibrated and ready for use.

Table 4. Solubility of dissolved oxygen in water at various temperatures and pressures

[Solubility of dissolved oxygen is in milligram per liter. $\mathrm{mm} / \mathrm{Hg}$, millimeter of mercury; ${ }^{\circ} \mathrm{C}$, degree Celsius]

\begin{tabular}{|c|c|c|c|c|c|c|c|c|c|c|}
\hline \multirow{2}{*}{$\begin{array}{c}\text { Water } \\
\text { temperature } \\
\left({ }^{\circ} \mathrm{C}\right)\end{array}$} & \multicolumn{10}{|c|}{ Atmospheric pressure $(\mathrm{mm} / \mathrm{Hg})^{1}$} \\
\hline & 760 & 740 & 720 & 700 & 680 & 660 & 640 & 620 & 600 & 580 \\
\hline 0.0 & 14.6 & 14.2 & 13.8 & 13.4 & 13.0 & 12.7 & 12.3 & 11.9 & 11.5 & 11.1 \\
\hline 2.0 & 13.8 & 13.4 & 13.1 & 12.7 & 12.3 & 12.0 & 11.6 & 11.2 & 10.9 & 10.5 \\
\hline 4.0 & 13.1 & 12.7 & 12.4 & 12.0 & 11.7 & 11.4 & 11.0 & 10.6 & 10.3 & 10.0 \\
\hline 6.0 & 12.4 & 12.1 & 11.8 & 11.4 & 11.1 & 10.8 & 10.4 & 10.1 & 9.8 & 9.5 \\
\hline 8.0 & 11.8 & 11.5 & 11.2 & 10.9 & 10.6 & 10.2 & 9.9 & 9.6 & 9.3 & 9.0 \\
\hline 10.0 & 11.3 & 11.0 & 10.7 & 10.4 & 10.1 & 9.8 & 9.5 & 9.2 & 8.9 & 8.6 \\
\hline 12.0 & 10.8 & 10.5 & 10.2 & 9.9 & 9.6 & 9.3 & 9.0 & 8.8 & 8.5 & 8.2 \\
\hline 14.0 & 10.3 & 10.0 & 9.7 & 9.5 & 9.2 & 8.9 & 8.6 & 8.4 & 8.1 & 7.8 \\
\hline 16.0 & 9.8 & 9.6 & 9.3 & 9.1 & 8.8 & 8.5 & 8.3 & 8.0 & 7.7 & 7.5 \\
\hline 18.0 & 9.4 & 9.2 & 8.9 & 8.7 & 8.4 & 8.2 & 7.9 & 7.7 & 7.4 & 7.2 \\
\hline 20.0 & 9.1 & 8.8 & 8.6 & 8.3 & 8.1 & 7.8 & 7.6 & 7.4 & 7.1 & 6.9 \\
\hline 22.0 & 8.7 & 8.5 & 8.2 & 8.0 & 7.8 & 7.5 & 7.3 & 7.1 & 6.8 & 6.6 \\
\hline 24.0 & 8.4 & 8.2 & 7.9 & 7.7 & 7.5 & 7.2 & 7.0 & 6.8 & 6.6 & 6.3 \\
\hline 26.0 & 8.1 & 7.9 & 7.6 & 7.4 & 7.2 & 7.0 & 6.8 & 6.5 & 6.3 & 6.1 \\
\hline 28.0 & 7.8 & 7.6 & 7.4 & 7.2 & 7.0 & 6.7 & 6.5 & 6.3 & 6.1 & 5.9 \\
\hline 30.0 & 7.5 & 7.3 & 7.1 & 6.9 & 6.7 & 6.5 & 6.3 & 6.1 & 5.9 & 5.7 \\
\hline
\end{tabular}

${ }^{1}$ R.F. Weiss (1970) Deep Sea Research, v. 17, p. 721. 


\section{Alr-Saturated Water}

This method calibrates the dissolved-oxygen meter using water saturated with oxygen at a known temperature and ambient atmospheric pressure.

1. Use approximately $1 \mathrm{~L}$ of DIW or native water. The temperature of the calibration water should be close to the ambient water temperature.

2. Place dissolved-oxygen probe and the calibration water in a large beaker or open-mouth container and allow the temperature to equilibrate.

3. Aerate the water for several minutes ( 3 to 5). This is most easily accomplished with a small battery-operated aquarium pump and a short section of tubing with a gas-diffusion stone attached.

CAUTION: It is extremely important to ensure that the water is 100 -percent saturated with oxygen. Observe meter while aerating calibration water. If no change in dissolved oxygen is observed for a period of 2 to 3 minutes, the water can be assumed to be saturated.

4. Read the ambient atmospheric pressure from the barometer to the nearest $5 \mathrm{~mm}$ of mercury. Recheck the REDLINE and ZERO reading on the oxygen meter and adjust if necessary.

5. Measure temperature in the water chamber to the nearest $0.5^{\circ} \mathrm{C}$ using the thermistor in the dissolved-oxygen probe.

6. Determine the dissolved-oxygen saturation value at the measured water temperature and true atmospheric pressure using table 4.

7. Select the scale $(0-10 \mathrm{mg} / \mathrm{L}$ or $1-20 \mathrm{mg} / \mathrm{L})$ to be used for the dissolved-oxygen measurement and adjust CALIBRATION control until meter reads the dissolved-oxygen saturation value determined from table 4 . Recalibrate if the scale is changed.

8. After calibration, check the dissolved-oxygen meter and probe in a dissolved-oxygen-free solution. This can be accomplished by inserting the probe into a sodium-sulfate/cobalt-chloride solution and measuring the dissolved oxygen. If the instrument reading exceeds $0.2 \mathrm{mg} / \mathrm{L}$, the membrane and electrolyte or the entire probe might need to be replaced. Thoroughly rinse probe with DIW to remove any residue of the zero-dissolved-oxygen solution.

Meter is now calibrated and ready to use. 
Dissolved-oxygen measurements should represent the mean dissolved-oxygen concentration at the time of measurement. Cross-sectional profiles will help to determine if the stream has a fairly uniform dissolved-oxygen concentration. If the stream cross section has uniform dissolved-oxygen concentrations, a single measurement can be made (usually at the centroid of flow). If the stream does not have uniform dissolved concentrations, or if a cross-sectional measurement has not been made, make several measurements and report an average (discharge-weighted average is preferred) concentration. Dissolved-oxygen measurements should not be made in or directly below stream sections with turbulent flow or in still water (near the streambank) because these conditions generally do not represent the majority of water flowing along the stream reach.

The dissolved oxygen should be measured with the probe immersed directly in the stream. If the stream velocity at the point of measurement is less than $1 \mathrm{ft} / \mathrm{s}$, use a stirrer or raise and lower the probe at a rate of approximately $1 \mathrm{ft} / \mathrm{s}$ (do not break the surface of the water). If the stream velocity is so high that the probe will not submerged, attach the probe to a small weight on a separate line.

1. Turn on the dissolved-oxygen meter to any operational position (for example, REDLINE) 1 hour before use to ensure stability of operation. Leave meter on until final measurement for the day is completed.

2. Turn operation switch to the range used during calibration.

3. Read and record the dissolved-oxygen values after the reading on the meter has stabilized (at least 2 minutes).

4. Turn the operation switch to REDLINE.

5. Remove the probe from the water, rinse with DIW, and store the probe tip in a storage bottle that contains a damp towel or immerse in DIW. Protect the probe from freezing.

6. Turn the operation switch to the OFF position after the final measurement of the day.

7. Report dissolved-oxygen concentrations to the nearest $0.2 \mathrm{mg} / \mathrm{L}$.

To express the results as percent saturation, use the following equation:

$$
\text { dissolved oxygen (percent saturation) }=\frac{\text { measured } D O(m g / L)}{D O \text { at saturation }(m g / L)} \times 100
$$

where DO is dissolved oxygen.

\section{DOCUMENTATION}

Field activities should be documented on standard surface-water-quality field notes. Figure 2 shows page 1 of the field notes. Pages 2, 3, and 4 include meter calibration information, quality assurance samples, alkalinity titration summary, and cross-section profile information. Complete all appropriate sections. A complete documentation will aid in future analyses of the collected information.

Field notes should include the following information:

a. Station name and number.

b. Date and mean time.

c. Gage height, discharge, or both; stage conditions.

d. Method of collection (for example, EWI or EDI).

e. Sampler and nozzle used (for example, DH-81, D-77).

f. Location of sampling cross section (for example, bridge, wading).

g. Number and locations of verticals sampled.

h. Compositing and splitting procedure.

i. Field analyses and calibration procedures (for example, water temperature, conductance, $\mathrm{pH}$ ).

j. Detailed alkalinity titration.

k. Type of samples collected (for example, nutrients, organic compound, quality control).

1. Name of sample collector(s).

m. Site information: sampling method and whether sampler limits were exceeded, vertical transit rate, color and odor of the stream, weather conditions, and additional information. 


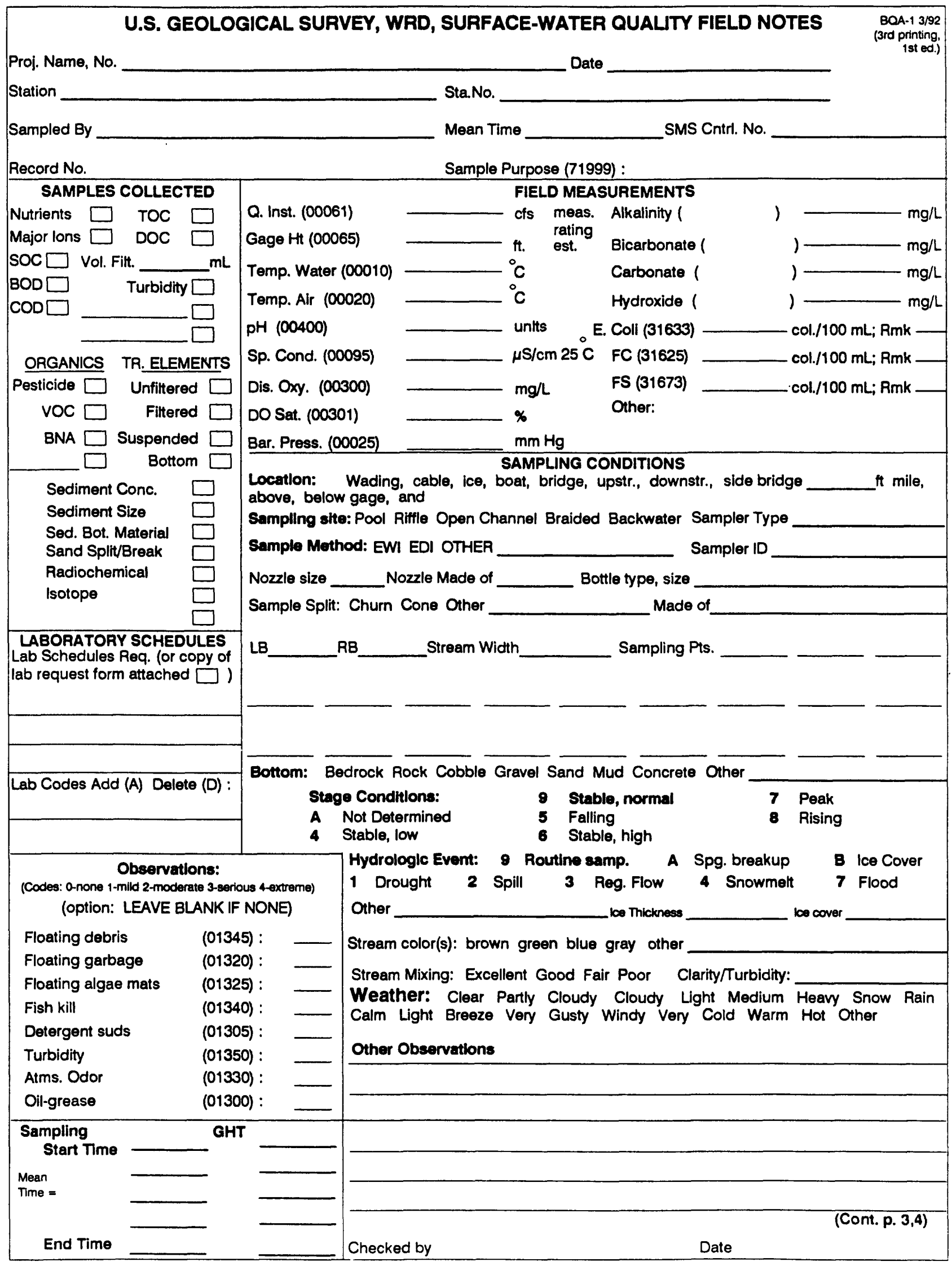

Figure 2. Surface-water quality field notes. 


\section{QUALITY ASSURANCE AND QUALITY CONTROL}

The sources of variability and bias introduced by sample collection and processing affect the interpretation of water-quality data. Establishment. of quality-assurance plans ensure that the data collected are compatible and of sufficient quality to meet program objectives. This field guide and accompanying references, along with the study-unit design guidelines for NAWQA, should be used by the study units when preparing quality-assurance plans. Specific details for quality-assurance plans are described in a report by Shampine and others (1992).

Investigators in each study unit must document the quality of their data by collecting quality-control samples. A series of quality-control samples (field blanks, replicates, and field-matrix-spike samples) is obtained in water-quality investigations (Shampine and others, 1992) because the quality of the data collected and the validity of any interpretation cannot be evaluated without quality-control data. Qualitycontrol samples should include the same sample set as the routinely scheduled samples. For the detailed procedures for preparing quality-control samples for organic compounds and the required percent of samples necessary, consult the NAWQA quality-assurance memorandums cited in appendix B. Qualitycontrol requirements for inorganic constituent sampling and processing are discussed in OWQ technical memorandum 94.09 (see appendix A).

\section{FIELD BLANKS}

Field blanks are designed to demonstrate that (1) equipment-cleaning protocols adequately remove residual contamination from previous use, (2) sampling and sample-processing procedures do not result in contamination, and (3) equipment handling and transport between periods of sample collection do not introduce contamination.

Field blanks for pesticides are collected immediately before processing native water through the sample-processing sequence for field samples. Preparation of field blanks requires passing a volume of organic-free DIW through all sample equipment contacted by the actual sample.

Field blanks for major ions and nutrients should be collected by the same approach, but using inorganic-free DIW after preparation of the organic blank.

\section{REPLICATES}

Sample replicates are designed to provide information needed to (1) estimate the precision of concentration values determined from the combined sample-processing and analytical scheme and (2) evaluate the consistency of identifying target analytes for pesticides. Each replicate sample is an aliquot of native sample water from a splitter and is processed immediately after the primary cone-split sample using the same equipment; placed into the same type of bottle; prepared in the same way by SPE, if applicable; and stored and shipped in the same way.

\section{FIELD-MATRIX SPIKES}

Field-matrix spikes are designed to (1) assess recoveries from field matrices and (2) assist in evaluating the precision of results for the range of target analytes in different matrices.

A field-matrix spike is prepared by adding a standard spike solution provided by NWQL to a split of sample water processed in the same way as the regular pesticide analysis. A separate matrix-spike sample for each of the two pesticide schedules is prepared, stored, and shipped to NWQL. Matrix-spike kits with instructions are available from NWQL. 


\section{References Cited}

Busenberg, Eurybiadas, and Plummer, L.N., 1987, pH measurement of low-conductivity waters: U.S. Geological Survey Water-Resources Investigations Report 87-4060, 22 p.

Capel, P.D., and Nacionales, F.C., 1993, Splitting device for water samples: U.S. Geological Survey Open-File Report CA491, $20 \mathrm{p}$.

Crawford, J.K., and Luoma, S.N., 1992, Guidelines for studies of contaminants in biological tissues for the National Water-Quality Assessment program: U.S. Geological Survey Open-File Report 92-494, 69 p.

Edwards, T.K., and Glysson, D.G., 1988, Field methods for measurement of fluvial sediment: U.S. Geological Survey Open-File Report 86-531, 118 p.

Fishman, M.J., and Friedman, L.C., eds., 1985, Methods for determination of inorganic substances in water and fluvial sediments: U.S. Geological Survey Techniques of Water-Resources Investigations, book 5, chap. A1, $545 \mathrm{p}$.

Gilliom, R.J., Alley, W.M., and Gurtz, M.E., 1994, Design of the National Water-Quality Assessment program: Occurrence and distribution assessment: U.S. Geological Survey Circular 1112, 33 p.

Hem, J.D., 1985, Study and interpretation of chemical characteristics of natural water: U.S. Geological Survey Water-Supply Paper 2254, 264 p.

Hirsch, R.M., Alley, W.M., and Wilber, W.G., 1988, Concepts for a National Water-Quality Assessment program: U.S. Geological Survey Circular 1021, 42 p.

Leahy, P.P., Rosenshein, J.S., and Knopman, D.S., 1990, Implementation plan for the National Water-Quality Assessment program: U.S. Geological Survey Open-File Report 90-174, 10 p.

Meador, M.R., Cuffney, T.F, and Gurtz, M.E., 1993, Methods for sampling fish communities as part of the National Water-Quality Assessment program: U.S. Geological Survey Open-File Report 93-104, 40 p.

Rantz, S.E., and others, 1982, Measurement and computation of streamflow: Volume 1, Measurement of Stage. Volume 2, Computation of discharge: U.S. Geological Survey Water-Supply Paper 2175, v. 1, p. 1-284, v. 2, p. 285-631.

Sandstrom, M.W., Wydoski, D.S., Schroeder, M.P., Zamboni, J.L., and Foreman, W.T., 1992, Methods of analysis by the U.S. Geological Survey National Water Quality Laboratory--determination of organonitrogen herbicides in water by solid-phase extraction and capillary-column gas chromatography/mass spectrometry with selected-ion monitoring: U.S. Geological Survey Open-File Report 91-519, 19 p.

Shelton, L.R., and Capel, P.D., 1994, Guidelines for collecting and processing samples of stream bed sediment for analysis of trace elements and organic contaminants for the National Water-Quality Assessment program: U.S. Geological Survey Open-File Report 94-458

Shampine, W.J., Pope, L.M., and Koterba, M.T., 1992, Integrating quality assurance in project work plans of the U.S. Geological Survey: U.S. Geological Survey Open-File Report 92-162, 12 p.

U.S. Geological Survey, 1978, Sediment, chapter 3 in U.S. Geological Survey, National handbook of recommended methods for water-data acquisition: p. 3-1 to 3-100.

Ward, J.R., and Hair, C.A., 1990, Methods for collection and processing of surface-water and bed-material samples for physical and chemical analyses: U.S. Geological Survey Open-File Report 90-140, 71 p.

Weiss, R.F., 1970, The solubility of nitrogen, oxygen, and argon in water and seawater: Deep Sea Research, v. 17, no. 4, p. 721-735.

Wood, W.W., 1981, Guidelines for collection and field analysis of ground-water samples for selected unstable constituents: U.S. Geological Survey Techniques of Water-Resources Investigations, book 1, chap. D2, 24 p. 


\section{APPENDIX A--SELECTED TECHNICAL MEMORANDUMS}

These Office of Water Quality (OWQ), Office of Surface Water (OSW) and Water Resources Division (WKD) memorandums are available in U.S. Geological Survey, Water Resources Division offices, nationwide.

OWQ 79.10 ANALYTICAL METHODS

OWQ 80.17 EQUIPMENT AND SUPPLIES

OWQ 81.02 WATER QUALITY

OWQ 81.08 WATER QUALITY

OWQ 81.17 EQUIPMENT AND SUPPLIES

OWQ 82.05 WATER QUALITY

OWQ 89.01 EQUIPMENT AND SUPPLIES

OWQ 90.01 WATER QUALITY

OWQ 91.02 PUBLICATIONS

OWQ 91.09 REPORTS

OWQ 91.10 PROGRAMS AND PLANS

OWQ 92.01 PROGRAMS AND PLANS

OWQ 92.02 FIELD TECHNIQUES

OWQ 92.06 FIELD TECHNIQUES

OWQ 92.11 FIELD TECHNIQUES

OWQ 92.12 PROGRAMS AND PLANS

OWQ 92.13 PROGRAMS AND PLANS

OWQ 93.05 PROGRAMS AND PLANS

OWQ 93.06 PROGRAMS AND PLANS

OWQ 93.11 PROGRAMS AND PLANS

OWQ 94.02 EQUIPMENT

OSW 94.05 EQUIPMENT
Recommended procedures for calibrating dissolved oxygen meters

New sample splitter for water-quality samples

Operation and availability - D-77 water-quality sampler

Electrodes for $\mathrm{pH}$ measurements in low-conductivity waters

YSI model 32 conductance meters

Method for dissolved carbonate, dissolved bicarbonate, and carbonate alkalinity

$\mathrm{pH}$ measurement in low conductivity waters

Sample preservation and ampule disposal

Methods for collection and processing of surface-water and bed-material samples for physical and chemical analyses

Filtration of water-sediment samples for the determination of organic compounds

Dissolved trace element data (contamination)

Dissolved/deionized water for district operations

Field preparation of containers for aqueous samples

Report of committee on sample shipping integrity and cost

Return of spent mercury and dichromate ampules to the national water quality laboratory

Trace element concentrations in deionized water processed through selected surface-water samplers

Trace element contamination: findings of studies on the cleaning of membrane filters and filtration systems

Evaluation of capsule filters

Trace element contamination--findings of study on the cleaning of sampler caps, nozzles, bottles, and bags

Implementation of the protocol for collecting and processing surface-water samples for low-level inorganic analyses

Discontinuance of field use of mercury liquid-in-glass thermometers

Maximum sampling depths and transit rates for suspended sediment and water-quality samplers 
WRD 94.06 SAFETY

WRD 94.07 SAFETY

OWQ 94.09 PROGRAMS AND PLANS

OWQ 94.13 EQUIPMENT

OWQ 94.16 PROGRAMS AND PLANS
Storage, transport, handling, and disposal of hydrochloric acid Storage, transport, handling and disposal of methyl alcohol

Revision of new division protocol for collecting and processing surface-water samples for low-level inorganic analyses.

Evaluation of churn splitter for inclusion in the division protocol for collection and processing of surface-water samples for subsequent determination of trace elements, nutrients, and major ions in filtered water.

New preservation techniques for nutrient samples.

\section{APPENDIX B--SELECTED INTERNAL COMMUNICATIONS}

These documents are available in U.S. Geological Survey, Water Resources Division offices where the National Water-Quality Assessment Program have active studies.

National Water-Quality Assessment program, U.S. Department of the Interior, written communication, U.S. Geological Survey memorandum dated July 15, 1993, on quality-assurance/quality-control plan for intensive-fixed sites.

National Water-Quality Assessment program, U.S. Department of the Interior, written communication, U.S. Geological Survey memorandum dated August 10,1993, on quality-assurance/quality-control plan for basic-fixed sites.

Sylvester, M.A., Kister, L.R., and Garrett, W.B., eds, 1990, Guidelines for collection, treatment, and analyses of water samples--U.S. Geological Survey Western Region Field Manual: U.S. Geological Survey, Western Region, Internal Document, $144 \mathrm{p}$. 